\title{
Anatomic Subsites and Prognosis of Gastric Signet Ring Cell Carcinoma: A SEER Population-based 1:1 Propensity-matched Study
}

\section{Yangyang Xie}

Hangzhou TCM Hospital Affiliated to Zhejiang Chinese Medical University

\section{Xue Song}

Hangzhou TCM Hospital Affiliated to Zhejiang Chinese Medical University

Haimin Jin

Hangzhou TCM Hospital Affiliated to Zhejiang Chinese Medical University

\section{Zhongkai Ni}

Hangzhou TCM Hospital Affiliated to Zhejiang Chinese Medical University

\section{Xiaowen Li}

Hangzhou TCM Hospital Affiliated to Zhejiang Chinese Medical University

\section{Shifei Huang}

Hangzhou TCM Hospital Affiliated to Zhejiang Chinese Medical University

\section{Lin Yan}

Hangzhou TCM Hospital Affiliated to Zhejiang Chinese Medical University

\section{Da Lin}

Hangzhou TCM Hospital Affiliated to Zhejiang Chinese Medical University

Hai Huang ( $\nabla$ szyyhuanghai@163.com )

Hangzhou TCM Hospital Affiliated to Zhejiang Chinese Medical University

\section{Research Article}

Keywords: Gastric Neoplasms, Tumor localization, Prognosis, Nomogram, SEER Program

Posted Date: April 16th, 2021

DOl: https://doi.org/10.21203/rs.3.rs-403278/v1

License: (c) (i) This work is licensed under a Creative Commons Attribution 4.0 International License.

Read Full License

Version of Record: A version of this preprint was published at BioMed Research International on January 30th, 2022. See the published version at https://doi.org/10.1155/2022/1565207. 


\section{Abstract}

Background: The dismal prognosis of gastric signet ring cell carcinoma (GSRC) is a global problem. The current study is conducted to comprehensively evaluate clinicopathological features and survival outcomes in GSRC patients stratified by anatomic subsites. Then predictive nomograms are constructed and validated to improve the effectiveness of personalized management.

Method: The patients diagnosed with GSRC were recruited from the online SEER database. The influence of anatomic subsites on overall survival (OS) and cancer-specific survival (CSS) was evaluated using multivariate Cox regression and Kaplan-Meier analysis. Then we employed propensity score matching (PSM) technique to decrease selection bias and balance patients' epidemiological factors. Predictive nomograms were constructed and validated.

Results: Multivariate Cox regression demonstrated that the patients with overlapping gastric cancer (OGC) suffered the highest mortality risk for OS (HR, 1.29; 95\% $\mathrm{Cl}, 1.23-1.36 ; \mathrm{P}<0.001)$ and CSS $(\mathrm{HR}, 1.33$; $95 \% \mathrm{Cl}, 1.28-1.37 ; \mathrm{P}<0.001)$. Age, TNM stage, tumor localization, tumor size, surgery and chemotherapy presented a highly significant relationship with OS and CSS. Following subgroup and PSM analysis, OGC patients were confirmed to have the worst OS and CSS. Then nomograms predicting 6 months, 12 months and 36 months OS and CSS were constructed. The calibration curves and reveiver operating characteristic curves demonstrated the great performance of the nomograms.

Conclusion: We identified anatomic subsites as a predictor of survival in those with GSRC. Patients with OGC suffered the highest mortality risk. The proposed nomograms allowed a relatively accurate survival prediction for GSRC patients.

\section{Introduction}

Gastric cancer (GC) is the fifth most frequently diagnosed malignancy and the third greatest cause of cancer-associated death worldwide[1]. Adenocarcinoma occupies the majority of GC[2]. Gastric signet ring cell carcinoma (GSRC) is a rare subtype of gastric adenocarcinoma, which is related to aggressive malignancy behavior and poor prognosis[3]. It's reported the occurrence rate of GSRC has gradually risen in the post three decades in the United States[4].

Anatomically, the stomach is classified into two prime subsites: the proximal section, which is composed of the cardia and fundus, and the distal section, which includes the body, antrum and pylorus. Some studies also include overlapping section, which denote that the tumor develops across two or more anatomic subsites [5]. Recently, it's demonstrated that cardia, non-cardia, and overlapping GC have divergent biological features and predisposing factors, which should be considered separately to investigate $\mathrm{GC}$ behavior[6]. And subsite-specific analysis can promote targeting prevention and therapy. However, no risk stratification by anatomic subsites has been made in the patients diagnosed with GSRC before. 
Herein, a population-based research was conducted to investigate the clinicopathological features and survival outcomes in GSRC incidence, stratified by anatomic subsites. And one-to-one propensity score matching (PSM) was made to exam the effect of tumor localization on GSRC prognosis. Besides, nomogram models to predict personal prognosis were constructed and validated based on multiinstitution and multi-population data from the Surveillance, Epidemiology, and End Result (SEER) database.

\section{Materials And Methods}

\section{Patients selection}

Patients were extracted from the SEER 18 regions database [Incidence-SEER 18 Regs Research Data (with additional treatment fields), Nov 2017 Sub (1975-2016 varying)] using SEER*Sat software (Version 8.3.5). We designed the following inclusion criteria: (1) age $\geq 18$ years at diagnosis; (2) histology ICD-0-3 (International Classification of Diseases for Oncology, $3^{\text {rd }}$ edition) confined only to signet ring cell carcinoma (8490/3); (3) Patients with complete demographic, clinic-pathological, treatment, and followup information.

Clinicopathological variables

Clinical features including tumor localization, age, race, marital status, gender, median household income, TNM grade, insurance status, tumor grade, $T$ stage, $N$ stage, $M$ stage, tumor size, regional nodes examined, distal organic metastasis, treatment methods and prognostic information were extracted for each patient. Based on the ICD-0-3 codes, anatomic subsites was characterized as follows: cardia (C16.0), fundus (C16.1), body (C16.2), antrum (C16.3), pylorus (C16.4), lesser curvature (C16.5), greater curvature (C16.6), overlapping (C16.8), and unspecified (C16.9), which is consistent with prior study[5]. Overlapping gastric cancer denoted that the tumor developed across two or more anatomic subsites. To avoid the inaccurate definition, only the vertical position classification (C16.0 to C16.4, C16.8) was included. As a result, the patients with tumor in cardia and fundus were divided into the proximal gastric cancer (PGC) group, while the tumor locating in corpus, antrum and pylorus were included in the distal gastric cancer (DGC) group, and overlapping lesion of stomach was in the overlapping gastric cancer (OGC) group. Age was categorized as 18-49 years, 50-59 years, 60-69 years, 70-79 years, and $\geq 80$ years. Race was divided into black, white, American Indian/Alaska Native (Al), and Asian or Pacific islander (API). Median house income was categorized as quartile 1, quartile 2, quartile 3 and quartile 4 from bottom to top. TNM staging system was based on the $7^{\text {th }}$ edition of the American Joint Committee on Cancer (AJCC). Radiation therapy and chemotherapy were classified into "yes" and "no/unknown". The study was exempted by institutional review boards due to the lack of subject identifiers and interventions.

Statistical analysis

The categorical variables were tested using the chi-square test. The primary endpoints were overall survival (OS) and cancer-specific survival (CSS). Kaplan-Meier (KM) curves and log-rank test were used to 
estimate survival distribution. Cox proportional hazard models were applied to perform univariate and multivariate analyses. The proportional hazard assumption was assessed using Schoenfeld residuals and was met for all models.

PSM was a novel statistical method which could minimize the heterogeneity and mimic randomized controlled trials[7]. It was performed to reevaluate the impact of anatomic subsites using one-to-one nearest-neighbor matching and a caliper width of 0.01 . Standardized difference (SD) were employed to examine the changes in covariate before and after PSM. SD $\leq 0.1$ denoted significant balances in the baseline variables[8].

The predictive ability of nomograms was assessed by calibration curves. In the calibration plot, 1000 bootstrap resamples were conducted to investigate the consistence of the predicted and observed probabilities of survival. Besides, the receiver operating characteristic (ROC) curves were plotted to show the prediction power of the constructed model, and the area under curve (AUC) value was listed. Higher AUC presented a stronger prediction power.

The statistical analyses were based on R software, version 4.0.3 (http://www.r-project.org) using packages of tableone, rms, survival, survminer, ggplot2, cobalt, pROC and Matchit. A two-tailed $\mathrm{P}<0.05$ was indicated statistically significant.

\section{Results}

Clinicopathological characteristics

A total of 2039 patients with GSRC from 2010 to 2015 were recruited in the SEER database. The clinicopathological features in each group were presented in Table 1.

The patients in the PGC group tended to be in the older age groups of 60-69 (31.1\%), 70-79 (20.5\%). The PGC group had more white patients (82\%), while there were more black (14.3\%) and API (21.4\%) patients in the DGC group. Male and female proportion was the highest in the PGC group (71.2\%) and DGC group (53.1\%) respectively. Socioeconomic status was divided into quartile $1(<51030)$, quartile 2 (\$51031-\$61237), quartile 3 (\$61238-\$74330), quartile 4 (>\$74331). Compared to the OGC and PGC group, the patients in the DGC group tended to have earlier stage (26.5\%), T stage (27.4\%), N stage (45.4\%), M stage (76.2\%) and smaller tumor size (17.3\%). The OGC group presented the highest bone metastasis proportion (6.0\%), but more liver metastasis (6\%) and lung metastasis (4.5\%) were found in the PGC group. The proportion of patients underwent surgery presented the largest (67.1\%) in the DGC group. And PGC patients had more intentions to receive radiation $(49.3 \%)$ and chemotherapy $(78.8 \%)$.

Effects of tumor localization on OS and CSS

The OS and CSS of GSRC patients were evaluated by KM analysis. Significant differences in OS and CSS were found based on tumor localization $(P<0.0001)$ (Figure 1). 
Univariate analysis demonstrated that tumor localization, age, race, marital status, median household income, TNM stage, tumor size, regional node examined, bone metastasis, liver metastasis, lung metastasis, surgery, radiation and chemotherapy were significantly associated with OS (Table 2) and CSS (Table 3) (all P<0.05).

The outcomes of multivariate Cox regression analysis demonstrated that the patients with DGC suffered relatively low risk for OS (OGC: HR, 1.29; 95\%Cl, 1.23-1.36; P<0.001; PGC: HR, 1.15; 95\%Cl, 1.09-1.22; $\mathrm{P}<0.001$ ) (Table 2) and CSS (OGC: HR, 1.33; 95\%Cl, 1.28-1.37; P<0.001; PGC: HR, 1.18; 95\%Cl, 1.10-1.23; $\mathrm{P}<0.001$ ) (Table 3). The result also presented that patients with OGC suffered the highest mortality risk. Age, TNM stage, tumor size, surgery and chemotherapy presented high levels of correlation with OS and CSS.

To decrease the impact of confounding factors, all GSRC patients were stratified based on clinical characteristics. It was identified that tumor localization was an independent prognostic factor of OS (Figure 2) and CSS (Figure 3) in the subgroups stratified by gender, surgery, radiation, chemotherapy and T stage (all $\mathrm{P}<0.05)$.

Survival analysis after 1:1 PSM

A one-to-one PSM was conducted to minimize the influence of potential confounders. Two matched groups were produced: a PGC and OGC cohort and a DGC and OGC cohort. The clinical baselines between both cohorts were balanced (Table 4). SD in most variables were less than 0.1 , which indicated good balancing performance (Figure 4). OGC patients presented worse OS and CSS in the PGC-OGC cohort and the DGC-OGC cohort after PSM (Figure 5).

Construction and validation of the nomogram

These six significant independent variables were applied to construct the prognostic nomograms to predict the 6 months, 12 months and 36 months OS and CSS of GSRC patients: age, TNM stage, tumor size, tumor localization, surgery and chemotherapy (Figure 6A and 7A).

The calibration curves for 6 months, 12 months and 36 months OS and CSS showed good consistence between the predicted and observed probabilities of survival (Figure 6B and 7B). Besides, the c-index for the constructed prognostic nomogram was calculated. In the OS group, it was $0.775(95 \% \mathrm{Cl}, 0.761-0.793)$ for 6 months survival, $0.789(95 \% \mathrm{Cl}, 0.776-0.801)$ for 12 months survival and $0.780(95 \% \mathrm{Cl}, 0.765-0.793)$ for 36 months survival, respectively. While in the CSS group, it was $0.771(95 \% \mathrm{Cl}, 0.758-0.790)$ for 6 months survival, $0.781(95 \% \mathrm{Cl}, 0.770-0.799)$ for 12 months survival and $0.773(95 \% \mathrm{Cl}, 0.762-0.790)$ for 36 months survival, respectively. The c-index was almost identical to the AUC of the ROC curve, which plotted the sensitivity against 1 -specificity for the probability of an outcome, demonstrating great discriminative ability (Figure $6 \mathrm{C}$ and $7 \mathrm{C}$ ).

\section{Discussion}


The SEER program included demographic and clinicopathological features in multiple malignancies from 18 population-based institutions, covering more than $30 \%$ of the U.S. population. This was the first research to investigate the effect of tumor location on GSRC prognosis using PSM in the SEER database. The results confirmed the concept that PGC, DCG and OGC were different malignant entities, which should be considered separately to improve GSRC incidence and verify driving risk factors. We found that three subgroups presented significantly different clinicopathological characteristics and survival outcomes for OS and CSS.

The PGC group had a significant higher proportion of male than other groups, which might attribute to the unhealthy diet and habits in men, such as smoking or alcohol abusing[9]. In addition, this research showed that the PGC group presented to be more frequent in aging population, which was similar to previous Chinese reports $[10,11]$. However, no correlation was found between age and tumor site in two European studies. The distinction might be partly due to the discrepancy of ethnic lines[12, 13]. In multivariate Cox analysis including an integrated range of variables, anatomic subsites were identified as a predictor of survival in those with GSRC. Patients with OGC suffered the highest mortality risk.

The prognosis in PGC and DGC still remained controversial. Majority of reports had demonstrated a significant poorer survival in PGC patients compared with DGC patients[10, 14-16], while no significant difference was found in other researcher[12,17]. Katsuhiko et al even reported a longer OS in patients with PGC[18]. The distinction might be associated with different staging and histology in different researches $[15,16]$. Furthermore, esophageal cancer was included into PGC in several studies, which led to confounding differences. However, few study concerned the role of OGC. In our study, the subtypes of GC were confined to GSRC, and the anatomic subsites were clearly defined as DGC, OGC and PGC. So the results were more convincing.

Before PSM, the results presented the best survival of DGC and the worst survival of OGC in OS, CSS and in the subgroups stratified by gender, surgery, radiation, chemotherapy and T stage. After PSM, we further confirmed that those who diagnosed with OGC suffered worse OS and CSS in the PGC-OGC cohort and DGC- OGC cohort. OGC denoted that the tumor developed across two or more anatomic subsites, which might presented more aggressive malignancy behavior than the one-site-confined tumor. This was similar to former researches. Thomassen et al founded that primary cancer of overlapping location was associated with higher odds for gastric cancer peritoneal carcinomatosis and worse survival[19]. Further studies should focus on the etiologies and behavior of overlapping section tumor in GSRC patients.

Nomograms had been regarded as efficient tools in clinical practice, which can predict numerical probabilities for individual patients by incorporating critical prognostic factors[20]. According to the recent studies, many nomograms had demonstrated superiority over the traditional TNM staging system in predicting patients survival in multiple malignancies[21-24]. In this study, nomograms were developed to predict personal survival for GSRC patients. On the basis of the multivariate analysis results, age, TNM stage, tumor size, tumor localization, surgery and chemotherapy were integrated into this predictive 
model. The nomograms showed good predictive ability for prognosis, which was supported by the calibration curve and ROC curves.

Limitation of the study includes the lack of comorbidities and chemotherapy regimens. These missing important variables may lead to potential bias. Also, this is a retrospective analysis, so selection bias are inevitably brought in. Further prospective research are necessary to confirm the conclusion. Despite these limitations, our substantial cases to investigate incidence by tumor location could provide novel insights on the epidemiology of GSRC.

\section{Conclusion}

This study identified that anatomic subsites as a predictor of survival in those with GSRC. Patients with OGC suffered the highest mortality risk. The constructed nomograms presented a relatively good performance and could be considered a practical tool to predict personal prognosis in GSRC patients. Further studies should be conducted separately to learn more about the etiologies of GSRC based on the different anatomic subsites.

\section{Declarations}

Ethics approval and consent to participate

The SEER database is publicly available and provides de-identified case data. So the study is exempted of ethics approval and informed consent due to the lack of subject identifiers and interventions.

Consent for publication

Not applicable

Availability of data and materials

The datasets generated and analyzed during the current study are available in the SEER database (https://seer.cancer.gov/) and from the corresponding authors upon reasonable request $\square$

Competing interests

The authors have no conflict of interests with any organizations or individuals.

Funding

Not applicable

Authors' contributions

Study design: Yangyang Xie, Hai Huang. 
Data collection: Yangyang Xie, Xue Song, Zhongkai Ni.

Statistical analysis: Yangyang Xie, Xue Song, Haimin Jin, Xiaowen Li.

Data interpretation: Yangyang Xie, Xue Song, Haimin Jin.

Manuscript preparation: Yangyang Xie, Zhongkai Ni, Shifei Huang, Lin Yan.

Literature search: Yangyang Xie, Xiaowen Li, Shifei Huang, Da Lin.

Acknowledgements

The authors gratefully thank the efforts of the SEER Program.

Authors' information (optional)

${ }^{1}$ Department of General Surgery, Hangzhou TCM Hospital Affiliated to Zhejiang Chinese Medical University, Hangzhou, Zhejiang province, 310000, China.

${ }^{2}$ Department of Pneumology, Hangzhou TCM Hospital Affiliated to Zhejiang Chinese Medical University, Hangzhou, Zhejiang province, 310000 , China.

Ethics approval and consent to participate

The SEER database is publicly available and provides de-identified case data. So the study is exempted of ethics approval and informed consent due to the lack of subject identifiers and interventions.

Consent for publication

Not applicable

Availability of data and materials

The datasets generated and analyzed during the current study are available in the SEER database (https://seer.cancer.gov/) and from the corresponding authors upon reasonable request $\square$

Competing interests

The authors have no conflict of interests with any organizations or individuals.

Funding

Not applicable

Authors' contributions

Study design: Yangyang Xie, Hai Huang. 
Data collection: Yangyang Xie, Xue Song, Zhongkai Ni.

Statistical analysis: Yangyang Xie, Xue Song, Haimin Jin, Xiaowen Li.

Data interpretation: Yangyang Xie, Xue Song, Haimin Jin.

Manuscript preparation: Yangyang Xie, Zhongkai Ni, Shifei Huang, Lin Yan.

Literature search: Yangyang Xie, Xiaowen Li, Shifei Huang, Da Lin.

Acknowledgements

The authors gratefully thank the efforts of the SEER Program.

Authors' information (optional)

${ }^{1}$ Department of General Surgery, Hangzhou TCM Hospital Affiliated to Zhejiang Chinese Medical University, Hangzhou, Zhejiang province, 310000 , China.

${ }^{2}$ Department of Pneumology, Hangzhou TCM Hospital Affiliated to Zhejiang Chinese Medical University, Hangzhou, Zhejiang province, 310000 , China.

\section{References}

1. Corso S, Giordano S. How Can Gastric Cancer Molecular Profiling Guide Future Therapies? Trends in molecular medicine. 2016; 22: 534-44.

2. Zhang X, Zhang P. Gastric cancer: somatic genetics as a guide to therapy. Journal of medical genetics. 2017; 54: 305-12.

3. Huang K, Chen M, Fang W, Lin C, Chao Y, Lo S, et al. The Clinicopathological Characteristics And Genetic Alterations of Signet-ring Cell Carcinoma in Gastric Cancer. Cancers. 2020; 12.

4. Henson D, Dittus C, Younes M, Nguyen H, Albores-Saavedra J. Differential trends in the intestinal and diffuse types of gastric carcinoma in the United States, 1973-2000: increase in the signet ring cell type. Archives of pathology \& laboratory medicine. 2004; 128: 765-70.

5. Wu H, Rusiecki J, Zhu K, Potter J, Devesa S. Stomach carcinoma incidence patterns in the United States by histologic type and anatomic site. Cancer epidemiology, biomarkers \& prevention : a publication of the American Association for Cancer Research, cosponsored by the American Society of Preventive Oncology. 2009; 18: 1945-52.

6. Gupta S, Tao L, Murphy J, Camargo M, Oren E, Valasek M, et al. Race/Ethnicity-, Socioeconomic Status-, and Anatomic Subsite-Specific Risks for Gastric Cancer. Gastroenterology. 2019; 156: 5962.e4.

7. Austin P. An Introduction to Propensity Score Methods for Reducing the Effects of Confounding in Observational Studies. Multivariate behavioral research. 2011; 46: 399-424. 
8. Austin P. Balance diagnostics for comparing the distribution of baseline covariates between treatment groups in propensity-score matched samples. Statistics in medicine. 2009; 28: 3083-107.

9. Kalish R, Clancy P, Orringer M, Appelman H. Clinical, epidemiologic, and morphologic comparison between adenocarcinomas arising in Barrett's esophageal mucosa and in the gastric cardia. Gastroenterology. 1984; 86: 461-7.

10. Yu X, Hu F, Li C, Yao Q, Zhang H, Xue Y. Clinicopathologic characteristics and prognosis of proximal and distal gastric cancer. OncoTargets and therapy. 2018; 11: 1037-44.

11. Huang Q, Fang C, Shi J, Sun Q, Wu H, Gold J, et al. Differences in Clinicopathology of Early Gastric Carcinoma between Proximal and Distal Location in 438 Chinese Patients. Scientific reports. 2015; 5: 13439.

12. Costa L, Toneto M, Moreira L. DO PROXIMAL AND DISTAL GASTRIC TUMOURS BEHAVE DIFFERENTLY? Arquivos brasileiros de cirurgia digestiva : $A B C D=$ Brazilian archives of digestive surgery. 2016; 29 : 232-5.

13. Piso $\mathrm{P}$, Werner $\mathrm{U}$, Lang $\mathrm{H}$, Mirena $\mathrm{P}$, Klempnauer J. Proximal versus distal gastric carcinoma--what are the differences? Annals of surgical oncology. 2000; 7: 520-5.

14. Petrelli F, Ghidini M, Barni S, Steccanella F, Sgroi G, Passalacqua R, et al. Prognostic Role of Primary Tumor Location in Non-Metastatic Gastric Cancer: A Systematic Review and Meta-Analysis of 50 Studies. Annals of surgical oncology. 2017; 24: 2655-68.

15. Kim M, Lee H, Yang H, Kim W. Clinicopathologic and protein expression differences between cardia carcinoma and noncardia carcinoma of the stomach. Cancer. 2005; 103: 1439-46.

16. Park J, Lee Y, Kim J, Kim Y, Lee S, Shin S, et al. Clinicopathological features and prognostic factors of proximal gastric carcinoma in a population with high Helicobacter pylori prevalence: a single-center, large-volume study in Korea. Annals of surgical oncology. 2010; 17: 829-37.

17. Liu K, Zhang W, Chen X, Chen X, Yang K, Zhang B, et al. Comparison on Clinicopathological Features and Prognosis Between Esophagogastric Junctional Adenocarcinoma (Siewert II/III Types) and Distal Gastric Adenocarcinoma: Retrospective Cohort Study, a Single Institution, High Volume Experience in China. Medicine. 2015; 94: e1386.

18. Higuchi K, Koizumi W, Tanabe S, Saigenji K, Ajani J. Chemotherapy is more active against proximal than distal gastric carcinoma. Oncology. 2004; 66: 269-74.

19. Irene, Thomassen, Yvette, R., van, Gestel, et al. Peritoneal carcinomatosis of gastric origin: A population-based study on incidence, survival and risk factors. International Journal of Cancer. 2013.

20. V V, RG vS, G L, MA G, MC B, M B, et al. Nomograms for predicting local recurrence, distant metastases, and overall survival for patients with locally advanced rectal cancer on the basis of European randomized clinical trials. Journal of clinical oncology : official journal of the American Society of Clinical Oncology. 2011; 29: 3163-72.

21. G X, M J, Y S, Y C, Z N. Prognostic value of the number of lymph nodes resected in patients with lymph-node-negative esophageal squamous cell carcinoma. International journal of clinical and experimental pathology. 2020; 13: 597-606. 
22. Z L, Q X, Y W, W W, S L, F S, et al. A Modified ypTNM Staging System-Development and External Validation of a Nomogram Predicting the Overall Survival of Gastric Cancer Patients Received Neoadjuvant Chemotherapy. Cancer management and research. 2020; 12: 2047-55.

23. J L, Y L, Y W, H L, F L, Q Z, et al. Prognostic nomogram based on the metastatic lymph node ratio for gastric neuroendocrine tumour: SEER database analysis. ESMO open. 2020; 5.

24. P L, Y Z, H W, X L, X X, Z H, et al. Prognostic Nomogram for Patients with Radical Surgery for NonMetastatic Colorectal Cancer Incorporating Hematological Biomarkers and Clinical Characteristics. OncoTargets and therapy. 2020; 13: 2093-102.

\section{Tables}


Table 1. The characteristics of patients with GSRC according to tumor localization in the SEER database.

\begin{tabular}{|c|c|c|c|c|c|}
\hline \multirow[t]{2}{*}{ Characteristics } & & \multirow{2}{*}{$\begin{array}{l}\text { DGC } \\
1084\end{array}$} & \multirow{2}{*}{$\begin{array}{l}\text { OGC } \\
351\end{array}$} & \multirow{2}{*}{$\begin{array}{l}\text { PGC } \\
604\end{array}$} & \multirow[t]{2}{*}{$P$ value } \\
\hline & & & & & \\
\hline \multirow[t]{5}{*}{ Age (\%) } & $18-49$ & $240(22.1)$ & $75(21.4)$ & $91(15.1)$ & \multirow[t]{5}{*}{$<0.001$} \\
\hline & $50-59$ & $249(23.0)$ & $93(26.5)$ & $\begin{array}{l}149 \\
(24.7)\end{array}$ & \\
\hline & $60-69$ & $242(22.3)$ & $90(25.6)$ & $\begin{array}{l}188 \\
(31.1)\end{array}$ & \\
\hline & $70-79$ & $218(20.1)$ & $59(16.8)$ & $\begin{array}{l}124 \\
(20.5)\end{array}$ & \\
\hline & $\geq 80$ & 135 (12.5) & $34(9.7)$ & $52(8.6)$ & \\
\hline \multirow[t]{4}{*}{ Race (\%) } & White & $691(63.7)$ & $255(72.6)$ & $\begin{array}{l}495 \\
(82.0)\end{array}$ & \multirow[t]{4}{*}{$<0.001$} \\
\hline & Black & $155(14.3)$ & $44(12.5)$ & $40(6.6)$ & \\
\hline & API & $232(21.4)$ & $49(14.0)$ & $64(10.6)$ & \\
\hline & Al & $6(0.6)$ & $3(0.9)$ & $5(0.8)$ & \\
\hline \multirow[t]{2}{*}{ Gender (\%) } & Male & $508(46.9)$ & 175 (49.9) & $\begin{array}{l}430 \\
(71.2)\end{array}$ & \multirow[t]{2}{*}{$<0.001$} \\
\hline & Female & $576(53.1)$ & $176(50.1)$ & $\begin{array}{l}174 \\
(28.8)\end{array}$ & \\
\hline \multirow[t]{4}{*}{ Marital status (\%) } & Divorced & $99(9.1)$ & $45(12.8)$ & 69 (11.4) & \multirow[t]{4}{*}{0.009} \\
\hline & Married & $646(59.6)$ & $212(60.4)$ & $\begin{array}{l}367 \\
(60.8)\end{array}$ & \\
\hline & Widowed & $147(13.6)$ & $38(10.8)$ & $48(7.9)$ & \\
\hline & Single & $192(17.7)$ & $56(16.0)$ & $\begin{array}{l}120 \\
(19.9)\end{array}$ & \\
\hline \multirow[t]{4}{*}{$\begin{array}{l}\text { Median household income } \\
(\%)\end{array}$} & Quartile 1 & $268(24.7)$ & $94(26.8)$ & $\begin{array}{l}183 \\
(30.3)\end{array}$ & \multirow[t]{4}{*}{0.017} \\
\hline & Quartile 2 & 299 (27.6) & $83(23.6)$ & $\begin{array}{l}128 \\
(21.2)\end{array}$ & \\
\hline & Quartile 3 & 247 (22.8) & $98(27.9)$ & $\begin{array}{l}141 \\
(23.3)\end{array}$ & \\
\hline & Quartile 4 & $269(24.8)$ & $76(21.7)$ & $\begin{array}{l}152 \\
(25.2)\end{array}$ & \\
\hline Insurance (\%) & Insured & 1025 (94.6) & 335 (95.4) & 587 & 0.126 \\
\hline
\end{tabular}


(97.2)

\begin{tabular}{|c|c|c|c|c|c|}
\hline & Uninsured & $49(4.5)$ & $13(3.7)$ & $12(2.0)$ & \\
\hline & Unknown & $10(0.9)$ & $3(0.9)$ & $5(0.8)$ & \\
\hline \multirow[t]{4}{*}{ Grade (\%) } & I & $1(0.1)$ & $1(0.3)$ & $0(0.0)$ & \multirow[t]{4}{*}{0.663} \\
\hline & II & $26(2.4)$ & $7(2.0)$ & $20(3.3)$ & \\
\hline & III & $1033(95.3)$ & 334 (95.2) & $\begin{array}{l}568 \\
(94.0)\end{array}$ & \\
\hline & IV & $24(2.2)$ & $9(2.6)$ & $16(2.6)$ & \\
\hline \multirow[t]{4}{*}{ TNM stage (\%) } & I & $287(26.5)$ & $44(12.5)$ & $82(13.6)$ & \multirow[t]{4}{*}{$<0.001$} \\
\hline & II & $211(19.5)$ & 45 (12.8) & $\begin{array}{l}118 \\
(19.5)\end{array}$ & \\
\hline & III & $328(30.3)$ & $128(36.5)$ & $\begin{array}{l}235 \\
(38.9)\end{array}$ & \\
\hline & IV & $258(23.8)$ & 134 (38.2) & $\begin{array}{l}169 \\
(28.0)\end{array}$ & \\
\hline \multirow[t]{4}{*}{ T stage (\%) } & T0/1 & $297(27.4)$ & $60(17.1)$ & $\begin{array}{l}143 \\
(23.7)\end{array}$ & \multirow[t]{4}{*}{$<0.001$} \\
\hline & T2 & $134(12.4)$ & $28(8.0)$ & 66 (10.9) & \\
\hline & T3 & $290(26.8)$ & $88(25.1)$ & $\begin{array}{l}273 \\
(45.2)\end{array}$ & \\
\hline & T4 & 363 (33.5) & 175 (49.9) & $\begin{array}{l}122 \\
(20.2)\end{array}$ & \\
\hline \multirow[t]{4}{*}{ N stage (\%) } & No & $492(45.4)$ & $141(40.2)$ & $\begin{array}{l}242 \\
(40.1)\end{array}$ & \multirow[t]{4}{*}{$<0.001$} \\
\hline & $\mathrm{N} 1$ & 237 (21.9) & $59(16.8)$ & $\begin{array}{l}223 \\
(36.9)\end{array}$ & \\
\hline & N2 & $129(11.9)$ & $44(12.5)$ & 76 (12.6) & \\
\hline & N3 & $226(20.8)$ & 107 (30.5) & $63(10.4)$ & \\
\hline \multirow[t]{2}{*}{ M stage (\%) } & MO & $826(76.2)$ & 217 (61.8) & $\begin{array}{l}435 \\
(72.0)\end{array}$ & \multirow[t]{2}{*}{$<0.001$} \\
\hline & M1 & $258(23.8)$ & $134(38.2)$ & $\begin{array}{l}169 \\
(28.0)\end{array}$ & \\
\hline \multirow[t]{3}{*}{ Tumor size (\%) } & $\leq 2 \mathrm{~cm}$ & $187(17.3)$ & $29(8.3)$ & 72 (11.9) & \multirow[t]{3}{*}{$<0.001$} \\
\hline & $\leq 5 \mathrm{~cm}$ & $320(29.5)$ & $53(15.1)$ & $\begin{array}{l}185 \\
(30.6)\end{array}$ & \\
\hline & $>5 \mathrm{~cm}$ & $257(23.7)$ & $116(33.0)$ & 135 & \\
\hline
\end{tabular}




\begin{tabular}{|c|c|c|c|c|c|}
\hline & Unknown & $320(29.5)$ & $153(43.6)$ & $\begin{array}{l}212 \\
(35.1)\end{array}$ & \\
\hline \multirow[t]{2}{*}{ Regional nodes examined (\%) } & $\leq 16$ & $706(65.1)$ & $236(67.2)$ & $\begin{array}{l}471 \\
(78.0)\end{array}$ & \multirow[t]{2}{*}{$<0.001$} \\
\hline & $>16$ & $378(34.9)$ & $115(32.8)$ & $\begin{array}{l}133 \\
(22.0)\end{array}$ & \\
\hline \multirow[t]{2}{*}{ Bone metastasis (\%) } & Yes & $24(2.2)$ & $21(6.0)$ & $28(4.6)$ & \multirow[t]{2}{*}{0.001} \\
\hline & No & $1060(97.8)$ & $330(94.0)$ & $\begin{array}{l}576 \\
(95.4)\end{array}$ & \\
\hline \multirow[t]{2}{*}{ Brain metastasis (\%) } & Yes & $3(0.3)$ & $0(0.0)$ & $3(0.5)$ & \multirow[t]{2}{*}{0.389} \\
\hline & No & $1081(99.7)$ & $351(100.0)$ & $\begin{array}{l}601 \\
(99.5)\end{array}$ & \\
\hline \multirow[t]{2}{*}{ Liver metastasis (\%) } & Yes & $32(3.0)$ & $16(4.6)$ & $36(6.0)$ & \multirow[t]{2}{*}{0.011} \\
\hline & No & $1052(97.0)$ & $335(95.4)$ & $\begin{array}{l}568 \\
(94.0)\end{array}$ & \\
\hline \multirow[t]{2}{*}{ Lung metastasis (\%) } & Yes & $24(2.2)$ & $10(2.8)$ & $27(4.5)$ & \multirow[t]{2}{*}{0.033} \\
\hline & No & $1060(97.8)$ & $341(97.2)$ & $\begin{array}{l}577 \\
(95.5)\end{array}$ & \\
\hline \multirow[t]{2}{*}{ Surgery (\%) } & No surgery & $357(32.9)$ & $152(43.3)$ & $\begin{array}{l}318 \\
(52.6)\end{array}$ & \multirow[t]{2}{*}{$<0.001$} \\
\hline & Surgery & $727(67.1)$ & $199(56.7)$ & $\begin{array}{l}286 \\
(47.4)\end{array}$ & \\
\hline \multirow[t]{2}{*}{ Radiation (\%) } & No/Unknown & $830(76.6)$ & $282(80.3)$ & $\begin{array}{l}306 \\
(50.7)\end{array}$ & \multirow[t]{2}{*}{$<0.001$} \\
\hline & Yes & $254(23.4)$ & $69(19.7)$ & $\begin{array}{l}298 \\
(49.3)\end{array}$ & \\
\hline \multirow[t]{2}{*}{ Chemotherapy (\%) } & No/Unknown & $440(40.6)$ & $109(31.1)$ & $\begin{array}{l}128 \\
(21.2)\end{array}$ & \multirow[t]{2}{*}{$<0.001$} \\
\hline & Yes & $644(59.4)$ & $242(68.9)$ & $\begin{array}{l}476 \\
(78.8)\end{array}$ & \\
\hline
\end{tabular}


Table 2. Impact of tumor localization on the OS by univariate and multivariate survival analysis before PSM

Characteristics

Tumor localization

DGC
OGC
PGC

Age

$\sqrt{2}+2$

Race

A

Marital status

API

Al

$18-49$
$50-59$
$60-69$
$70-79$
$\geq 80$

76.2

Univariate analysis Log rank $\chi^{2} \quad P$ value 49.4

DGC

OGC

PGC

White

Black

12.3

28.3

Divorced

Married

Widowed

Single
Median household income

Quartile 1

Quartile 2

Quartile 3

Quartile 4

16.7

\begin{tabular}{l} 
Quartile 1 \\
Quartile 2 \\
Quartile 3 \\
\hline Quartile 4
\end{tabular}

TNM stage $<0.001$

Multivariate analysis

$\mathrm{HR} \quad 95 \% \mathrm{Cl} \quad$ P value

Reference

$1.29 \quad 1.23-1.36<0.001$

$1.15 \quad 1.09-1.22<0.001$

$<0.001$

Reference

$1.01 \quad 0.84-1.22 \quad 0.886$

$1.04 \quad 0.87-1.26 \quad 0.644$

$1.72 \quad 1.41-2.11<0.001$

$1.71 \quad 1.35-2.17 \quad<0.001$

0.007

Reference

$1.07 \quad 0.89-1.28 \quad 0.467$

$0.89 \quad 0.75-1.06 \quad 0.192$

$1.12 \quad 0.57-2.20 \quad 0.733$

$<0.001$

Reference

$0.98 \quad 0.81-1.19 \quad 0.858$

$1.04 \quad 0.81-1.34 \quad 0.758$

$\begin{array}{lll}1.08 & 0.86-1.35 \quad 0.508\end{array}$

$<0.001$ 


\begin{tabular}{|c|c|c|c|c|c|}
\hline & & \multicolumn{3}{|c|}{ Reference } \\
\hline & \multicolumn{2}{|l|}{ ॥ } & 1.84 & $1.45-2.34$ & $<0.001$ \\
\hline & \multicolumn{2}{|l|}{ III } & 3.54 & $2.84-4.41$ & $<0.001$ \\
\hline & \multicolumn{2}{|c|}{ IV } & 4.22 & $3.34-5.32$ & $<0.001$ \\
\hline \multirow[t]{5}{*}{ Tumor size } & 244.6 & $<0.001$ & & & \\
\hline & \multicolumn{2}{|l|}{$\leq 2$} & \multicolumn{3}{|c|}{ Reference } \\
\hline & \multicolumn{2}{|l|}{$\leq 5$} & 1.47 & $1.14-1.88$ & 0.002 \\
\hline & \multicolumn{2}{|l|}{$>5 \mathrm{~cm}$} & 2.05 & $1.59-2.64$ & $<0.001$ \\
\hline & \multicolumn{2}{|l|}{ Unknown } & 2.01 & $1.57-2.58$ & $<0.001$ \\
\hline \multirow[t]{3}{*}{ Regional node examined } & 122.1 & $<0.001$ & & & \\
\hline & \multicolumn{2}{|l|}{$\leq 16$} & \multicolumn{3}{|c|}{ Reference } \\
\hline & \multicolumn{2}{|l|}{$>16$} & 0.83 & $0.70-0.99$ & 0.041 \\
\hline \multirow[t]{3}{*}{ Bone metastasis } & 81.6 & $<0.001$ & & & \\
\hline & \multicolumn{2}{|l|}{ Yes } & \multicolumn{3}{|c|}{ Reference } \\
\hline & \multicolumn{2}{|l|}{ No } & 0.86 & $0.65-1.14$ & 0.290 \\
\hline \multirow[t]{3}{*}{ Liver metastasis } & 87.0 & $<0.001$ & & & \\
\hline & \multicolumn{2}{|l|}{ Yes } & \multicolumn{3}{|c|}{ Reference } \\
\hline & \multicolumn{2}{|l|}{ No } & 0.88 & $0.68-1.13$ & 0.309 \\
\hline \multirow[t]{3}{*}{ Lung metastasis } & 74.3 & $<0.001$ & & & \\
\hline & \multicolumn{2}{|c|}{ Yes } & \multicolumn{3}{|c|}{ Reference } \\
\hline & \multicolumn{2}{|l|}{ No } & 0.86 & $0.63-1.17$ & 0.331 \\
\hline \multirow[t]{3}{*}{ Surgery } & 527.7 & $<0.001$ & & & \\
\hline & \multicolumn{2}{|c|}{ No } & \multicolumn{3}{|c|}{ Reference } \\
\hline & \multicolumn{2}{|l|}{ Yes } & 0.35 & $0.29-0.42$ & $<0.001$ \\
\hline \multirow[t]{3}{*}{ Radiation } & 22.6 & $<0.001$ & & & \\
\hline & No/unknown & & Refer & & \\
\hline & Yes & & 0.98 & $0.84-1.14$ & 0.801 \\
\hline Chemotherapy & 11.0 & $<0.001$ & & & \\
\hline & No/unknown & & Refere & & \\
\hline
\end{tabular}


Table 3. Impact of tumor localization on the CSS by univariate and multivariate survival analysis before PSM

Characteristics

Tumor localization
Univariate analysis

Log rank $\chi^{2}$

47.0

DGC

OGC

PGC

Age

$18-49$

50-59

60-69

70-79

$\geq 80$

Race

API

Marital status

Median household income

White

Black

API

Al

Al

16.8

Divorced

Married

Widowed

Single

15.7

Quartile 1

Quartile 2

Quartile 3

Quartile 4

471.1

45.0

13.9
P value $\mathrm{HR} \quad 95 \% \mathrm{Cl} \quad \mathrm{P}$ value

$<0.001$

\begin{tabular}{lrr}
\multicolumn{4}{l}{ Reference } \\
1.33 & $1.28-1.37$ & $<0.001$ \\
1.18 & $1.10-1.23$ & $<0.001$
\end{tabular}

$<0.001$

Reference

$1.00 \quad 0.83-1.21 \quad 0.972$

$1.02 \quad 0.85-1.23 \quad 0.816$

$1.70 \quad 1.39-2.09<0.001$

$1.46 \quad 1.14-1.88 \quad 0.003$

0.003

Reference

$1.01 \quad 0.84-1.22 \quad 0.896$

$0.86 \quad 0.72-1.03 \quad 0.093$

$\begin{array}{lll}1.07 & 0.53-2.19 \quad 0.843\end{array}$

$<0.001$

Reference

$0.98 \quad 0.81-1.19 \quad 0.843$

$1.01 \quad 0.78-1.31 \quad 0.954$

$1.04 \quad 0.83-1.30$

0.751

0.001

Reference

$0.90 \quad 0.80-1.02 \quad 0.090$

$1.05 \quad 0.93-1.19 \quad 0.388$

$0.90 \quad 0.79-1.01 \quad 0.080$

TNM stage $<0.001$

Page 18/29 


\begin{tabular}{|c|c|c|c|c|c|c|}
\hline & \multicolumn{3}{|l|}{ I } & \multicolumn{3}{|c|}{ Reference } \\
\hline & \multicolumn{3}{|c|}{ II } & 1.88 & $1.46-2.42$ & $<0.001$ \\
\hline & \multicolumn{3}{|l|}{ III } & 3.77 & $2.98-4.75$ & $<0.001$ \\
\hline & \multicolumn{3}{|l|}{ IV } & 4.62 & $3.62-5.90$ & $<0.001$ \\
\hline \multirow[t]{5}{*}{ Tumor size } & \multicolumn{2}{|l|}{247.9} & \multicolumn{4}{|l|}{$<0.001$} \\
\hline & \multicolumn{3}{|l|}{$\leq 2$} & \multicolumn{3}{|c|}{ Reference } \\
\hline & \multicolumn{3}{|l|}{$\leq 5$} & 1.50 & $1.15-1.96$ & 0.003 \\
\hline & \multicolumn{3}{|l|}{$>5 \mathrm{~cm}$} & 2.15 & $1.64-2.81$ & $<0.001$ \\
\hline & \multicolumn{3}{|l|}{ Unknown } & 2.07 & $1.59-2.69$ & $<0.001$ \\
\hline \multirow[t]{3}{*}{ Regional node examined } & 116.8 & & $<0.001$ & & & \\
\hline & \multicolumn{3}{|l|}{$\leq 16$} & \multicolumn{3}{|c|}{ Reference } \\
\hline & \multicolumn{3}{|l|}{$>16$} & 0.85 & $0.71-1.02$ & 0.074 \\
\hline \multirow[t]{3}{*}{ Bone metastasis } & & 83.4 & $<0.001$ & & & \\
\hline & \multicolumn{3}{|l|}{ Yes } & \multicolumn{3}{|c|}{ Reference } \\
\hline & \multicolumn{3}{|l|}{ No } & 0.86 & $0.64-1.15$ & 0.299 \\
\hline \multirow[t]{3}{*}{ Liver metastasis } & & 94.0 & $<0.001$ & & & \\
\hline & \multicolumn{3}{|l|}{ Yes } & \multicolumn{3}{|c|}{ Reference } \\
\hline & \multicolumn{3}{|l|}{ No } & 0.88 & $0.68-1.14$ & 0.321 \\
\hline \multirow[t]{3}{*}{ Lung metastasis } & & 74.2 & $<0.001$ & & & \\
\hline & \multicolumn{3}{|l|}{ Yes } & \multicolumn{3}{|c|}{ Reference } \\
\hline & \multicolumn{3}{|l|}{ No } & 0.87 & $0.63-1.19$ & 0.374 \\
\hline \multirow[t]{3}{*}{ Surgery } & & 525.4 & $<0.001$ & & & \\
\hline & \multicolumn{3}{|l|}{ No } & Refer & & \\
\hline & Yes & & & 0.34 & $0.28-0.40$ & $<0.001$ \\
\hline Radiation & & 22.2 & $<0.001$ & & & \\
\hline & No/unknown & & & Refer & & \\
\hline & Yes & & & 0.97 & $0.83-1.13$ & 0.707 \\
\hline Chemotherapy & 6.5 & & 0.010 & & & \\
\hline & No/unknown & & & Refer & & \\
\hline
\end{tabular}


CSS-cancer-specific survival; PSM-propensity score matching; HR-hazard ratio; Cl-confidence interval 


\begin{tabular}{|c|c|c|c|c|c|c|c|}
\hline \multirow[t]{2}{*}{ Characteristic } & & PGC & OGC & \multirow{2}{*}{$\begin{array}{l}\mathrm{P} \\
\text { value }\end{array}$} & DGC & OGC & \multirow{2}{*}{$\begin{array}{l}\mathrm{P} \\
\text { value }\end{array}$} \\
\hline & & 220 & 220 & & 310 & 310 & \\
\hline \multirow[t]{5}{*}{ Age (\%) } & $18-49$ & $\begin{array}{l}40 \\
(18.2)\end{array}$ & $\begin{array}{l}48 \\
(21.8)\end{array}$ & 0.514 & $\begin{array}{l}72 \\
(23.2)\end{array}$ & $\begin{array}{l}68 \\
(21.9)\end{array}$ & 0.812 \\
\hline & $50-59$ & $\begin{array}{l}59 \\
(26.8)\end{array}$ & $\begin{array}{l}60 \\
(27.3)\end{array}$ & & $\begin{array}{c}74 \\
(23.9)\end{array}$ & $\begin{array}{l}81 \\
(26.1)\end{array}$ & \\
\hline & $60-69$ & $\begin{array}{l}57 \\
(25.9)\end{array}$ & $\begin{array}{l}60 \\
(27.3)\end{array}$ & & $\begin{array}{l}70 \\
(22.6)\end{array}$ & $\begin{array}{l}73 \\
(23.5)\end{array}$ & \\
\hline & $70-79$ & $\begin{array}{l}49 \\
(22.3)\end{array}$ & $\begin{array}{l}35 \\
(15.9)\end{array}$ & & $\begin{array}{l}66 \\
(21.3)\end{array}$ & $\begin{array}{l}56 \\
(18.1)\end{array}$ & \\
\hline & $\geq 80$ & $\begin{array}{l}15 \\
(6.8)\end{array}$ & $\begin{array}{l}17 \\
(7.7)\end{array}$ & & $\begin{array}{l}28 \\
(9.0)\end{array}$ & $\begin{array}{l}32 \\
(10.3)\end{array}$ & \\
\hline \multirow[t]{4}{*}{ Race (\%) } & White & $\begin{array}{l}167 \\
(75.9)\end{array}$ & $\begin{array}{l}164 \\
(74.5)\end{array}$ & 0.886 & $\begin{array}{l}223 \\
(71.9)\end{array}$ & $\begin{array}{l}222 \\
(71.6)\end{array}$ & 0.957 \\
\hline & Black & $\begin{array}{l}20 \\
(9.1)\end{array}$ & $\begin{array}{l}25 \\
(11.4)\end{array}$ & & $\begin{array}{l}42 \\
(13.5)\end{array}$ & $\begin{array}{l}41 \\
(13.2)\end{array}$ & \\
\hline & API & $\begin{array}{l}32 \\
(14.5)\end{array}$ & $\begin{array}{l}30 \\
(13.6)\end{array}$ & & $\begin{array}{l}42 \\
(13.5)\end{array}$ & $\begin{array}{l}45 \\
(14.5)\end{array}$ & \\
\hline & $\mathrm{Al}$ & $\begin{array}{c}1 \\
(0.5)\end{array}$ & $\begin{array}{c}1 \\
(0.5)\end{array}$ & & $\begin{array}{c}3 \\
(1.0)\end{array}$ & $\begin{array}{c}2 \\
(0.6)\end{array}$ & \\
\hline \multirow[t]{2}{*}{ Gender (\%) } & Male & $\begin{array}{l}129 \\
(58.6)\end{array}$ & $\begin{array}{l}137 \\
(62.3)\end{array}$ & 0.495 & $\begin{array}{l}146 \\
(47.1)\end{array}$ & $\begin{array}{l}155 \\
(50.0)\end{array}$ & 0.52 \\
\hline & Female & $\begin{array}{c}91 \\
(41.4)\end{array}$ & $\begin{array}{l}83 \\
(37.7)\end{array}$ & & $\begin{array}{l}164 \\
(52.9)\end{array}$ & $\begin{array}{l}155 \\
(50.0)\end{array}$ & \\
\hline \multirow[t]{4}{*}{ Marital status (\%) } & Divorced & $\begin{array}{l}32 \\
(14.5)\end{array}$ & $\begin{array}{l}28 \\
(12.7)\end{array}$ & 0.858 & $\begin{array}{l}33 \\
(10.6)\end{array}$ & $\begin{array}{l}31 \\
(10.0)\end{array}$ & 0.827 \\
\hline & Married & $\begin{array}{l}131 \\
(59.5)\end{array}$ & $\begin{array}{l}128 \\
(58.2)\end{array}$ & & $\begin{array}{l}194 \\
(62.6)\end{array}$ & $\begin{array}{l}192 \\
(61.9)\end{array}$ & \\
\hline & Widowed & $\begin{array}{c}19 \\
(8.6)\end{array}$ & $\begin{array}{l}20 \\
(9.1)\end{array}$ & & $\begin{array}{l}30 \\
(9.7)\end{array}$ & $\begin{array}{l}37 \\
(11.9)\end{array}$ & \\
\hline & Single & $\begin{array}{l}38 \\
(17.3)\end{array}$ & $\begin{array}{l}44 \\
(20.0)\end{array}$ & & $\begin{array}{l}53 \\
(17.1)\end{array}$ & $\begin{array}{l}50 \\
(16.1)\end{array}$ & \\
\hline \multirow[t]{3}{*}{ Grade (\%) } & 1 & 0 & 0 & 0.966 & $\begin{array}{c}0 \\
(0.0)\end{array}$ & $\begin{array}{c}1 \\
(0.3)\end{array}$ & 0.646 \\
\hline & II & $\begin{array}{c}3 \\
(1.4)\end{array}$ & $\begin{array}{c}3 \\
(1.4)\end{array}$ & & $\begin{array}{c}5 \\
(1.6)\end{array}$ & $\begin{array}{c}7 \\
(2.3)\end{array}$ & \\
\hline & III & 210 & 209 & & 299 & 294 & \\
\hline
\end{tabular}




\begin{tabular}{|c|c|c|c|c|c|c|c|}
\hline & & $(95.5)$ & $(95.0)$ & & $(96.5)$ & $(94.8)$ & \\
\hline & IV & $\begin{array}{c}7 \\
(3.2)\end{array}$ & $\begin{array}{c}8 \\
(3.6)\end{array}$ & & $\begin{array}{l}6 \\
(1.9)\end{array}$ & $\begin{array}{c}8 \\
(2.6)\end{array}$ & \\
\hline \multirow[t]{4}{*}{ TNM stage (\%) } & 1 & $\begin{array}{l}29 \\
(13.2)\end{array}$ & $\begin{array}{l}34 \\
(15.5)\end{array}$ & 0.718 & $\begin{array}{l}47 \\
(15.2)\end{array}$ & $\begin{array}{l}44 \\
(14.2)\end{array}$ & 0.907 \\
\hline & II & $\begin{array}{l}35 \\
(15.9)\end{array}$ & $\begin{array}{l}29 \\
(13.2)\end{array}$ & & $\begin{array}{l}39 \\
(12.6)\end{array}$ & $\begin{array}{l}44 \\
(14.2)\end{array}$ & \\
\hline & III & $\begin{array}{l}76 \\
(34.5)\end{array}$ & $\begin{array}{l}71 \\
(32.3)\end{array}$ & & $\begin{array}{l}115 \\
(37.1)\end{array}$ & $\begin{array}{l}110 \\
(35.5)\end{array}$ & \\
\hline & IV & $\begin{array}{l}80 \\
(36.4)\end{array}$ & $\begin{array}{l}86 \\
(39.1)\end{array}$ & & $\begin{array}{l}109 \\
(35.2)\end{array}$ & $\begin{array}{l}112 \\
(36.1)\end{array}$ & \\
\hline \multirow[t]{4}{*}{ Tumor size (\%) } & $\leq 2 \mathrm{~cm}$ & $\begin{array}{l}31 \\
(14.1)\end{array}$ & $\begin{array}{l}23 \\
(10.5)\end{array}$ & 0.439 & $\begin{array}{c}26 \\
(8.4)\end{array}$ & $\begin{array}{l}29 \\
(9.4)\end{array}$ & 0.937 \\
\hline & $\leq 5 \mathrm{~cm}$ & $\begin{array}{l}35 \\
(15.9)\end{array}$ & $\begin{array}{l}41 \\
(18.6)\end{array}$ & & $\begin{array}{l}51 \\
(16.5)\end{array}$ & $\begin{array}{l}53 \\
(17.1)\end{array}$ & \\
\hline & $>5 \mathrm{~cm}$ & $\begin{array}{l}70 \\
(31.8)\end{array}$ & $\begin{array}{l}62 \\
(28.2)\end{array}$ & & $\begin{array}{l}103 \\
(33.2)\end{array}$ & $\begin{array}{l}105 \\
(33.9)\end{array}$ & \\
\hline & Unknown & $\begin{array}{l}84 \\
(38.2)\end{array}$ & $\begin{array}{l}94 \\
(42.7)\end{array}$ & & $\begin{array}{l}130 \\
(41.9)\end{array}$ & $\begin{array}{l}123 \\
(39.7)\end{array}$ & \\
\hline \multirow[t]{2}{*}{$\begin{array}{l}\text { Regional nodes } \\
\text { examined (\%) }\end{array}$} & $\leq 16$ & $\begin{array}{l}160 \\
(72.7)\end{array}$ & $\begin{array}{l}162 \\
(73.6)\end{array}$ & 0.914 & $\begin{array}{l}196 \\
(63.2)\end{array}$ & $\begin{array}{l}206 \\
(66.5)\end{array}$ & 0.449 \\
\hline & $>16$ & $\begin{array}{l}60 \\
(27.3)\end{array}$ & $\begin{array}{l}58 \\
(26.4)\end{array}$ & & $\begin{array}{l}114 \\
(36.8)\end{array}$ & $\begin{array}{l}104 \\
(33.5)\end{array}$ & \\
\hline \multirow[t]{2}{*}{ Bone metastasis (\%) } & Yes & $\begin{array}{l}13 \\
(5.9)\end{array}$ & $\begin{array}{l}16 \\
(7.3)\end{array}$ & 0.701 & $\begin{array}{c}7 \\
(2.3)\end{array}$ & $\begin{array}{c}7 \\
(2.3)\end{array}$ & 1 \\
\hline & No & $\begin{array}{l}207 \\
(94.1)\end{array}$ & $\begin{array}{l}204 \\
(92.7)\end{array}$ & & $\begin{array}{l}303 \\
(97.7)\end{array}$ & $\begin{array}{l}303 \\
(97.7)\end{array}$ & \\
\hline \multirow[t]{2}{*}{ Liver metastasis (\%) } & Yes & $\begin{array}{c}8 \\
(3.6)\end{array}$ & $\begin{array}{l}13 \\
(5.9)\end{array}$ & 0.371 & $\begin{array}{l}17 \\
(5.5)\end{array}$ & $\begin{array}{c}9 \\
(2.9)\end{array}$ & 0.161 \\
\hline & No & $\begin{array}{l}212 \\
(96.4)\end{array}$ & $\begin{array}{l}207 \\
(94.1)\end{array}$ & & $\begin{array}{l}293 \\
(94.5)\end{array}$ & $\begin{array}{l}301 \\
(97.1)\end{array}$ & \\
\hline \multirow[t]{2}{*}{ Lung metastasis (\%) } & Yes & $\begin{array}{c}8 \\
(3.6)\end{array}$ & $\begin{array}{c}9 \\
(4.1)\end{array}$ & 1 & $\begin{array}{c}10 \\
(3.2)\end{array}$ & $\begin{array}{c}9 \\
(2.9)\end{array}$ & 1 \\
\hline & No & $\begin{array}{l}212 \\
(96.4)\end{array}$ & $\begin{array}{l}211 \\
(95.9)\end{array}$ & & $\begin{array}{l}300 \\
(96.8)\end{array}$ & $\begin{array}{l}301 \\
(97.1)\end{array}$ & \\
\hline \multirow[t]{2}{*}{ Surgery (\%) } & No & $\begin{array}{l}101 \\
(45.9)\end{array}$ & $\begin{array}{l}105 \\
(47.7)\end{array}$ & 0.774 & $\begin{array}{l}123 \\
(39.7)\end{array}$ & $\begin{array}{l}129 \\
(41.6)\end{array}$ & 0.683 \\
\hline & Yes & $\begin{array}{l}119 \\
(54.1)\end{array}$ & $\begin{array}{l}115 \\
(52.3)\end{array}$ & & $\begin{array}{l}187 \\
(60.3)\end{array}$ & $\begin{array}{l}181 \\
(58.4)\end{array}$ & \\
\hline
\end{tabular}




\begin{tabular}{|llllllll|} 
Radiation (\%) & No/Unknown & $\begin{array}{l}160 \\
(72.7)\end{array}$ & $\begin{array}{l}165 \\
(75.0)\end{array}$ & 0.664 & 245 & 251 & 0.616 \\
& & & $(79.0)$ & $(81.0)$ & \\
& Yes & 60 & 55 & 65 & 59 & \\
& & $(27.3)$ & $(25.0)$ & & $(21.0)$ & $(19.0)$ & \\
\hline Chemotherapy (\%) & No/Unknown & 61 & 63 & 0.916 & 108 & 102 & 0.671 \\
& & $(27.7)$ & $(28.6)$ & & $(34.8)$ & $(32.9)$ & \\
& Yes & 159 & 157 & & 202 & 208 & \\
& & $(72.3)$ & $(71.4)$ & & $(65.2)$ & $(67.1)$ & \\
\hline
\end{tabular}

\section{Figures}

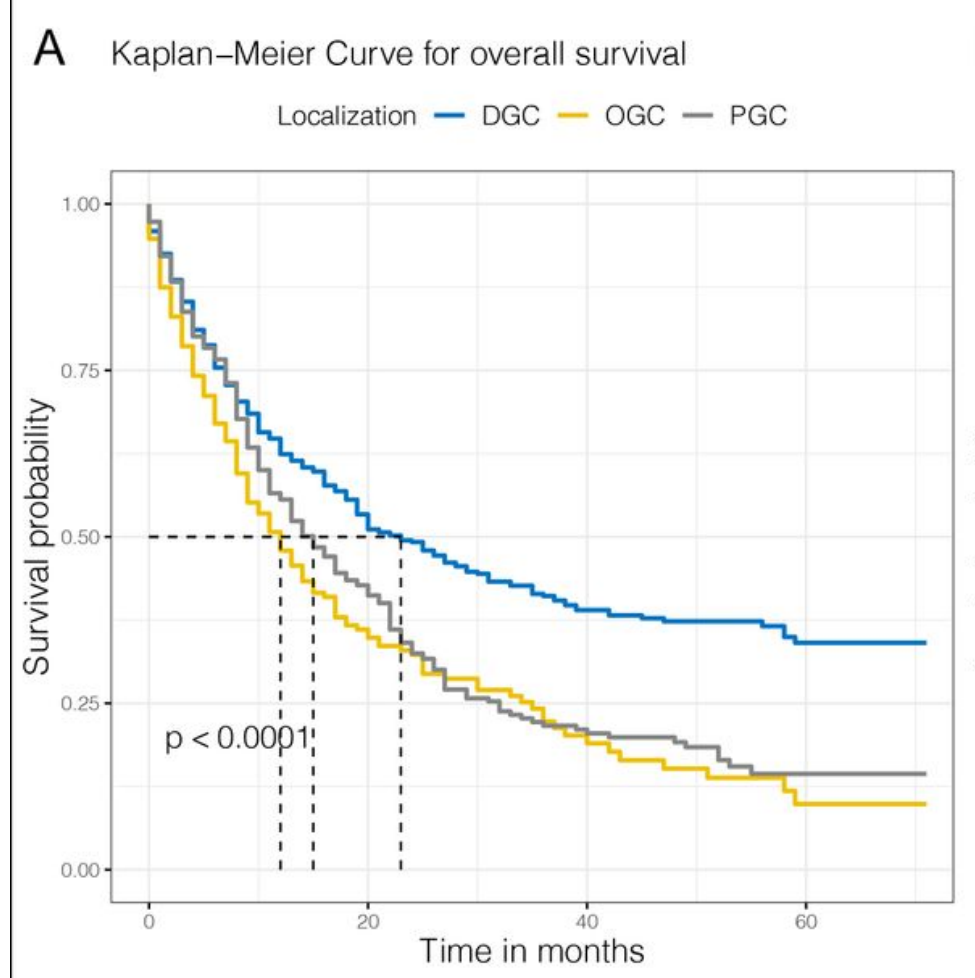

B Kaplan-Meier Curve for cancer-specific survival

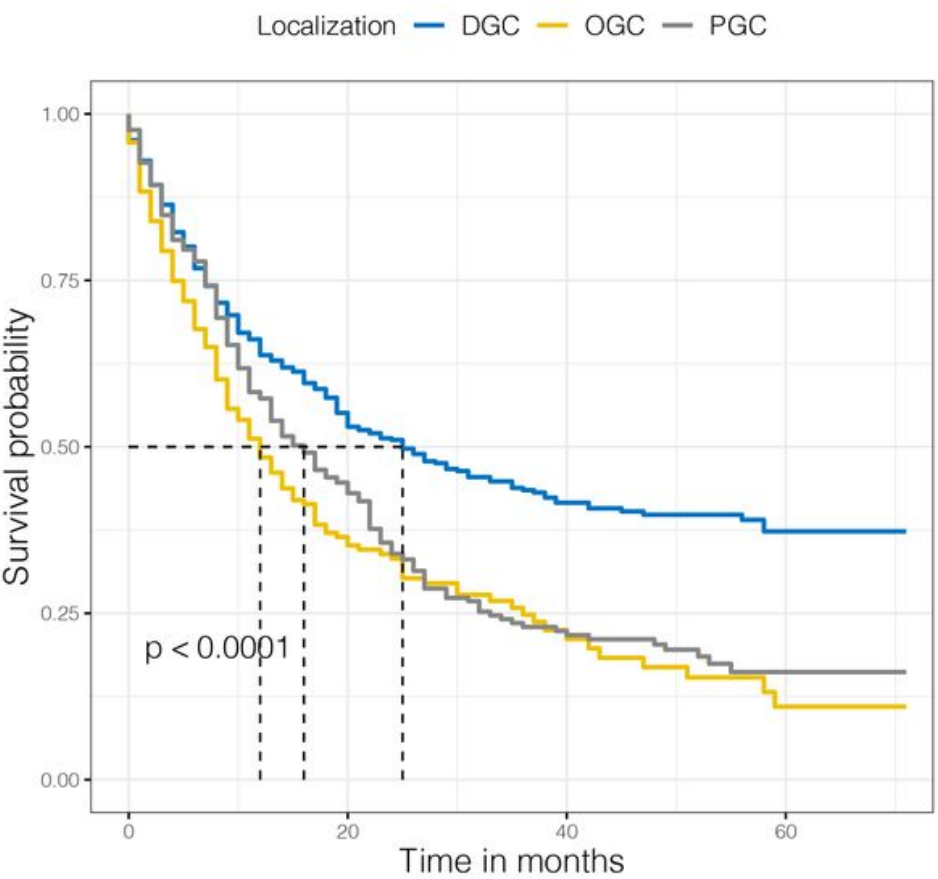

\section{Figure 1}

Overall survival (A) and cancer-specific survival (B) curves of GSRC based on tumor localization. 
A

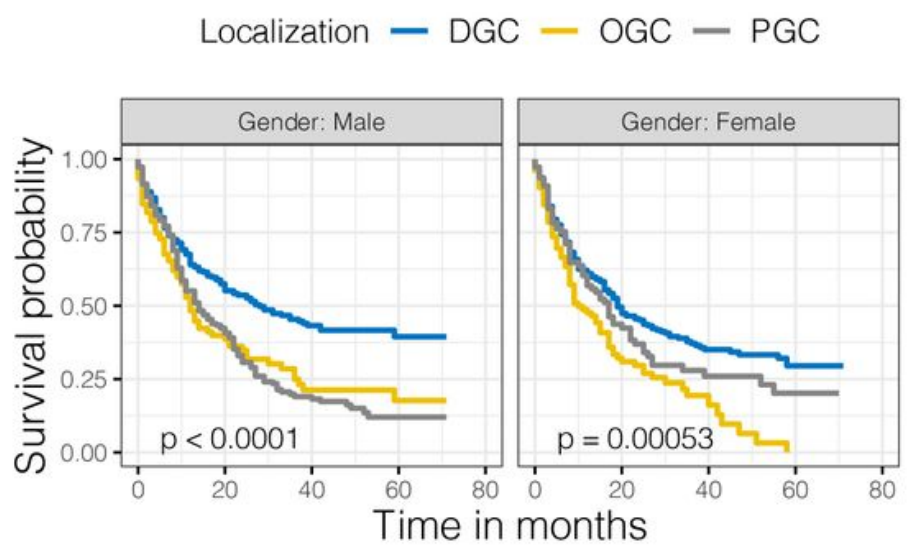

C

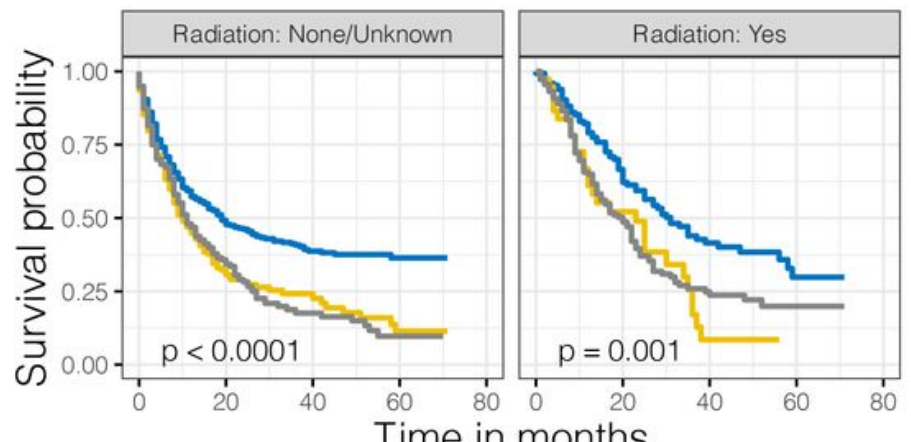

Time in months
B

Localization - DGC - OGC - PGC

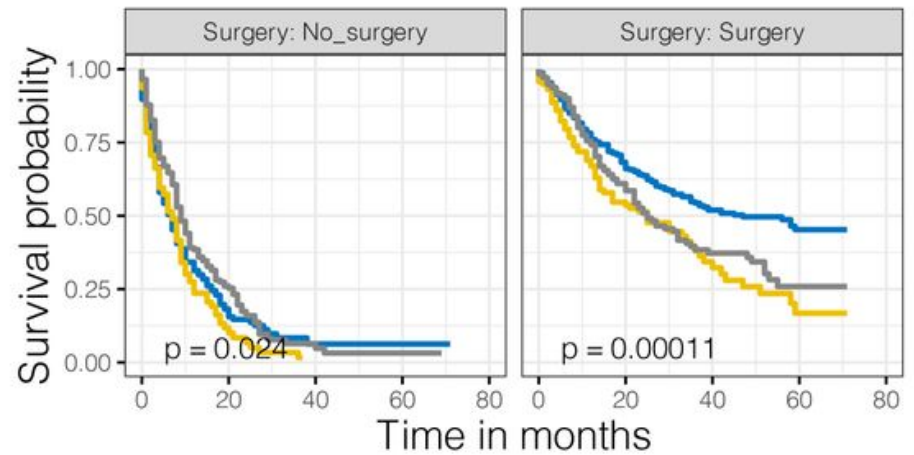

D

Localization - DGC - OGC - PGC

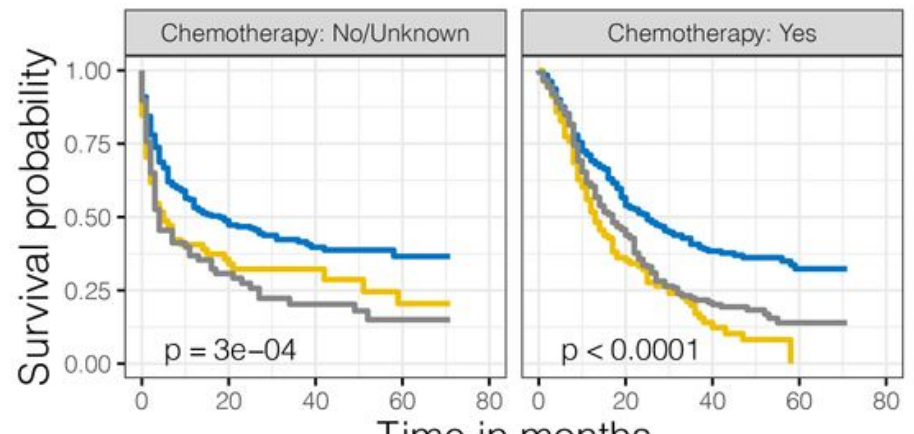

Time in months

E

Localization - DGC - OGC - PGC
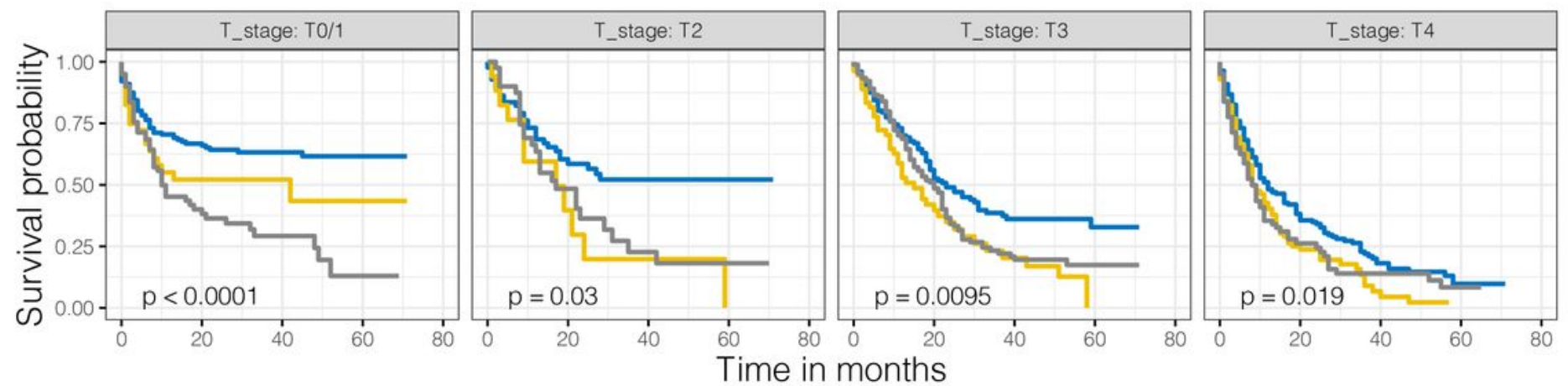

Time in months

Figure 2

Kaplan-Meier analysis for overall survival in subgroups stratified by gender (A), surgery (B), radiation (C), chemotherapy (D) and T stage (E). 
A

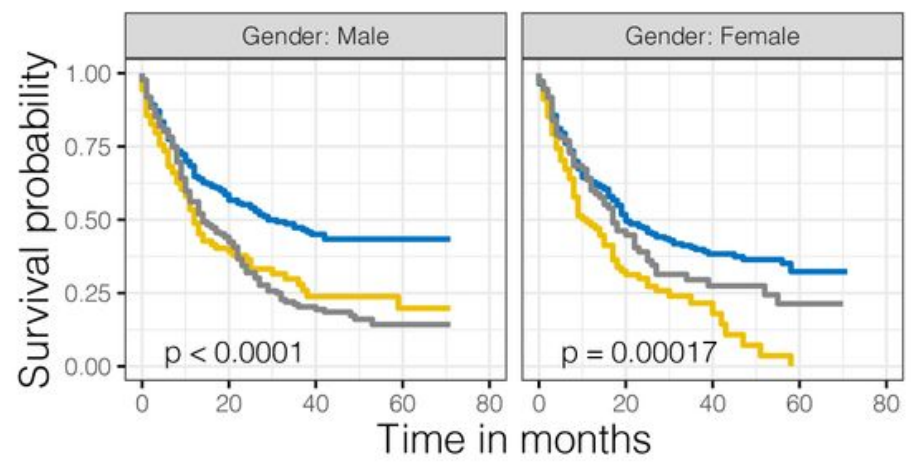

C

$$
\text { Localization - DGC - OGC - PGC }
$$

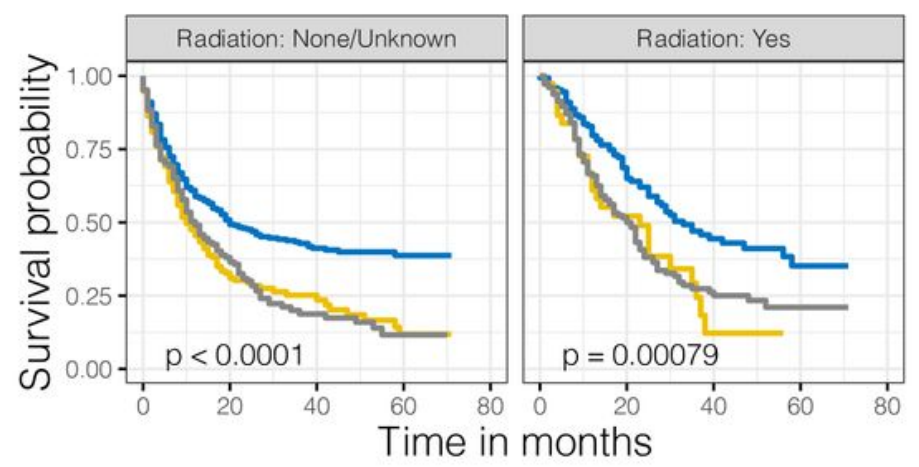

$E$

$$
\text { Localization - DGC - OGC - PGC }
$$
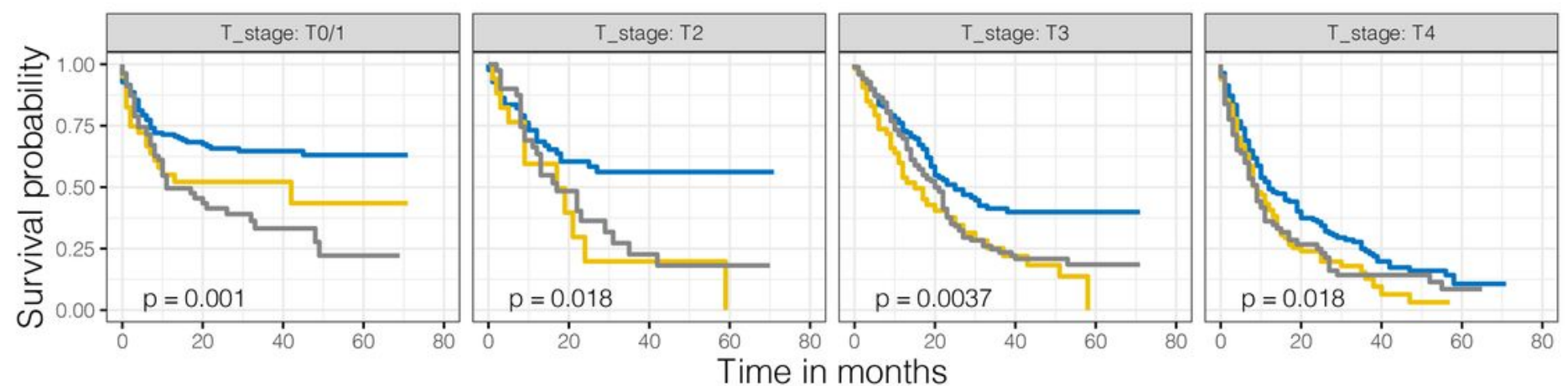

Time in months

\section{Figure 3}

Kaplan-Meier analysis for cancer-specific survival in subgroups stratified by gender (A), surgery (B), radiation $(C)$, chemotherapy $(D)$ and $T$ stage $(E)$. 

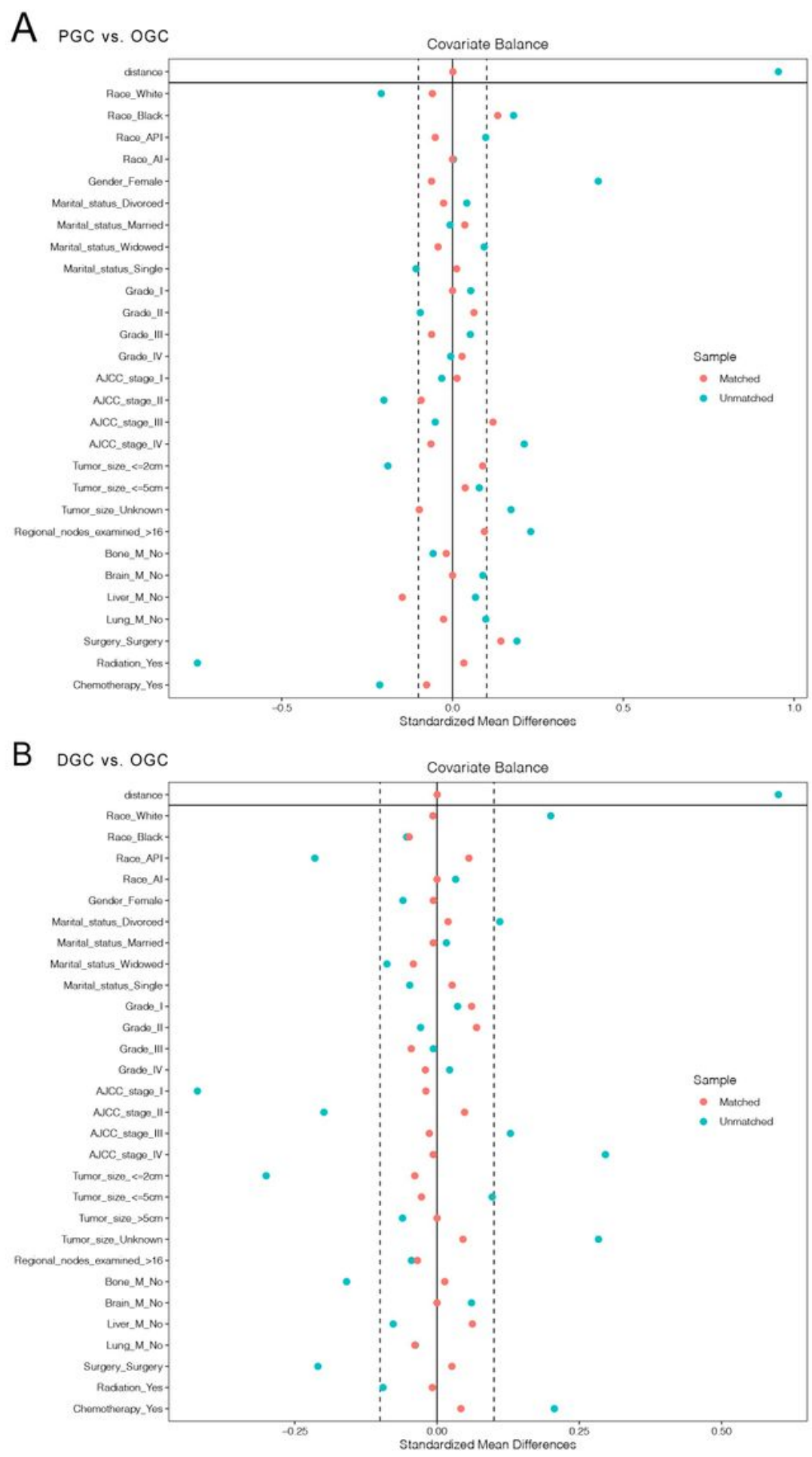

\section{Figure 4}

(A) The mean difference in all factors before and after PSM between PGC and OGC groups. (B) The mean difference between DGC and OGC groups. 
A Kaplan-Meier Curve for overall survival

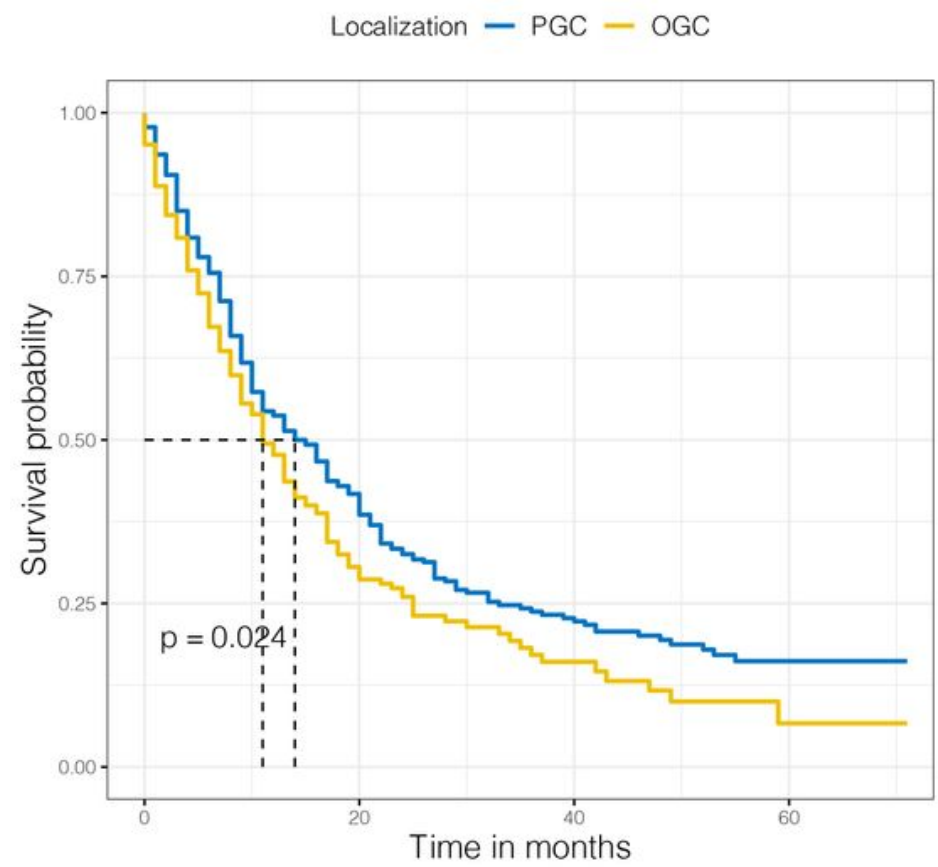

C Kaplan-Meier Curve for overall survival

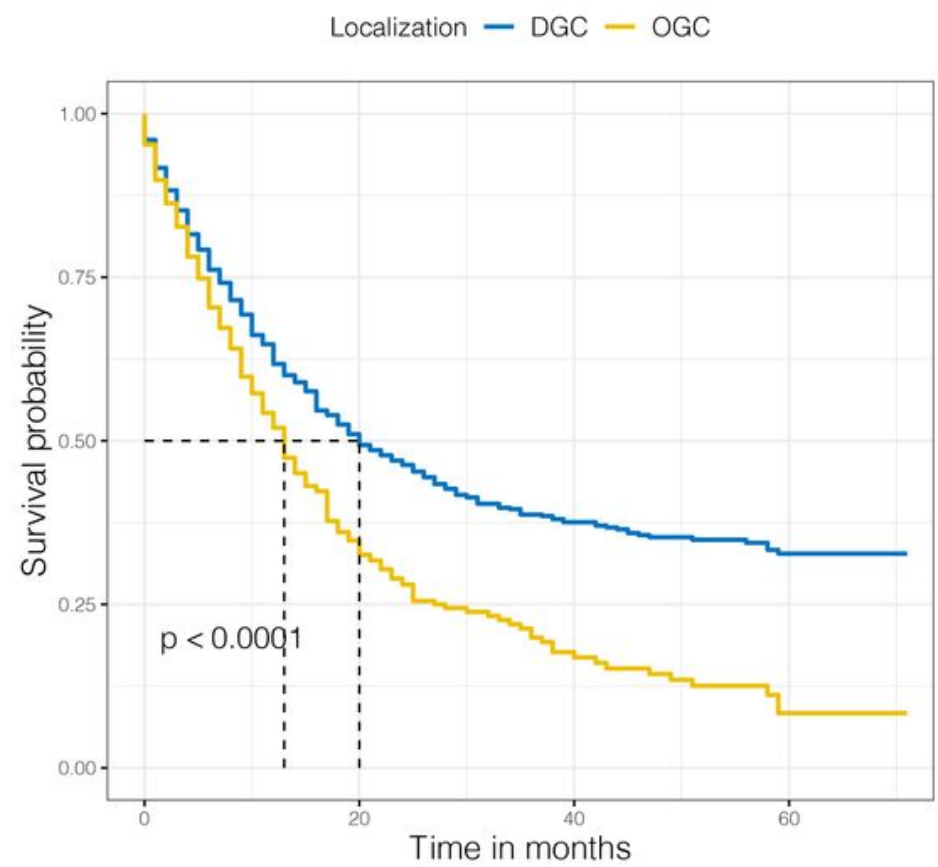

B Kaplan-Meier Curve for cancer-specific survival

Localization - PGC - OGC

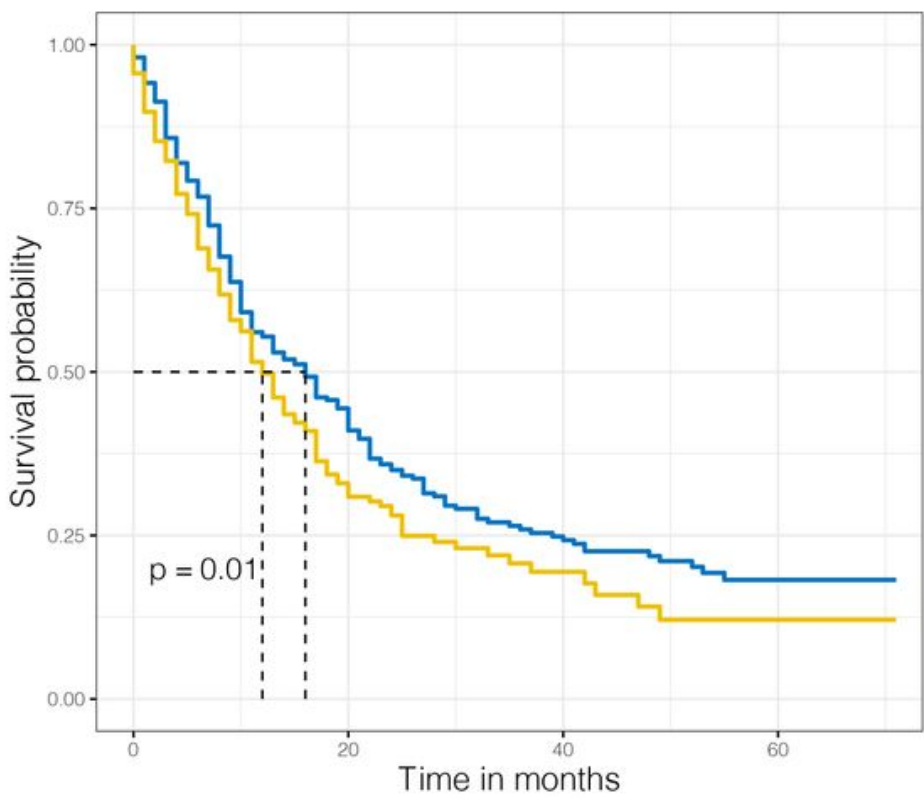

D Kaplan-Meier Curve for cancer-specific survival

Localization - DGC - OGC

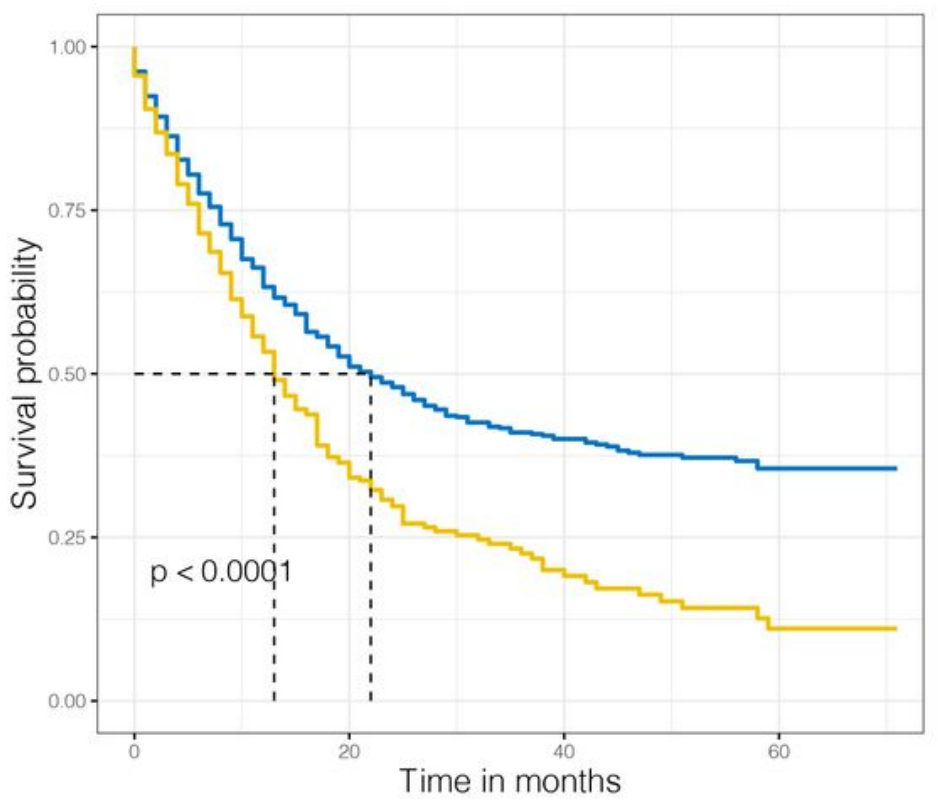

\section{Figure 5}

The overall survival (A, C) and cancer-specific survival $(B, D)$ of patients with GSRC according to tumor localization after PSM. 
A

Points

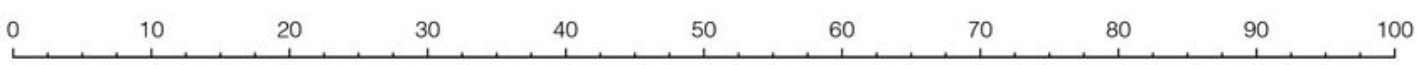

Age

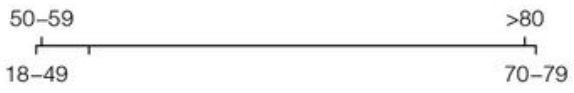

AJCC_stage

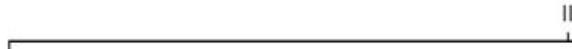

II

IV

Tumor_size

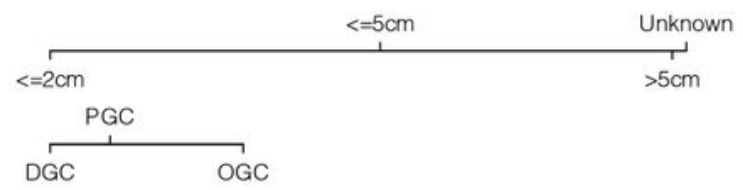

Localization

Surgery

Chemotherapy

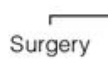

No_surgery

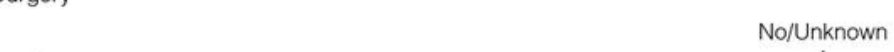

Total Points

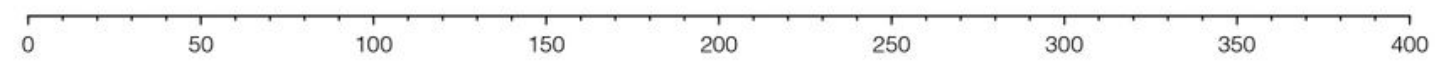

6 months Survival

12 months Survival
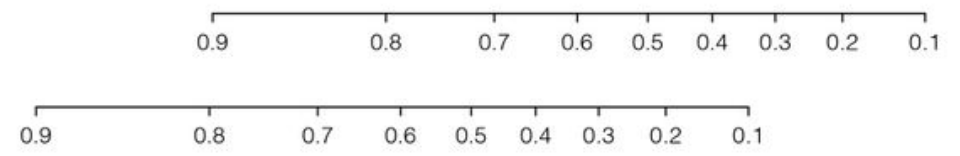

36 months survival

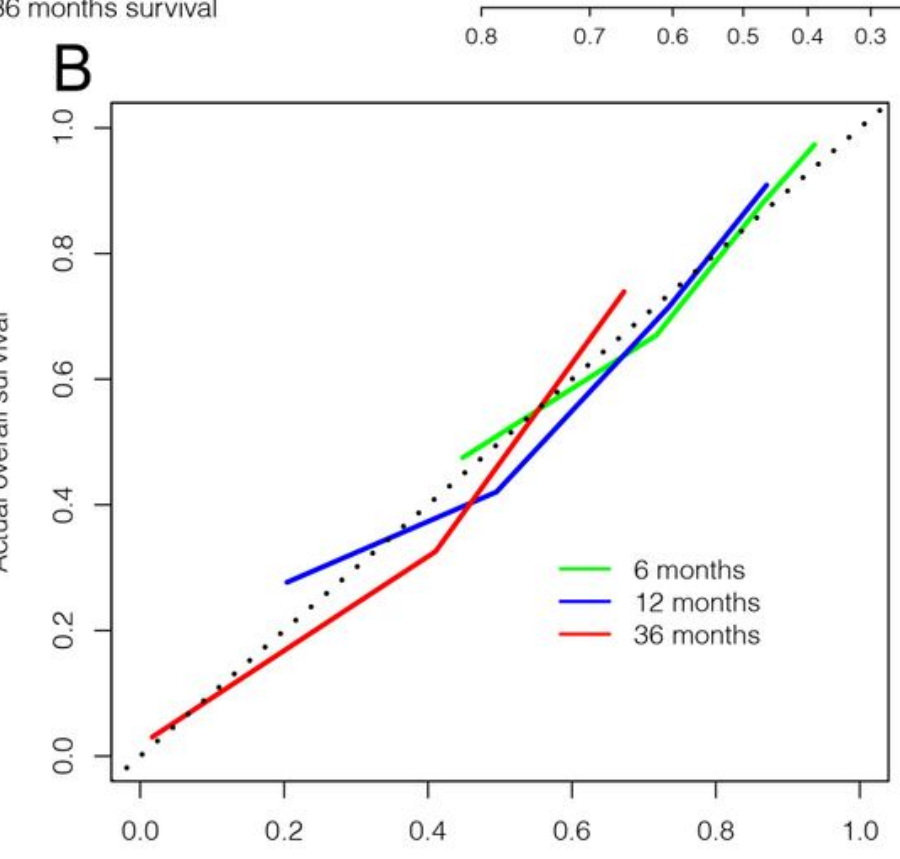

Nomogram-predicted probability of overall survival

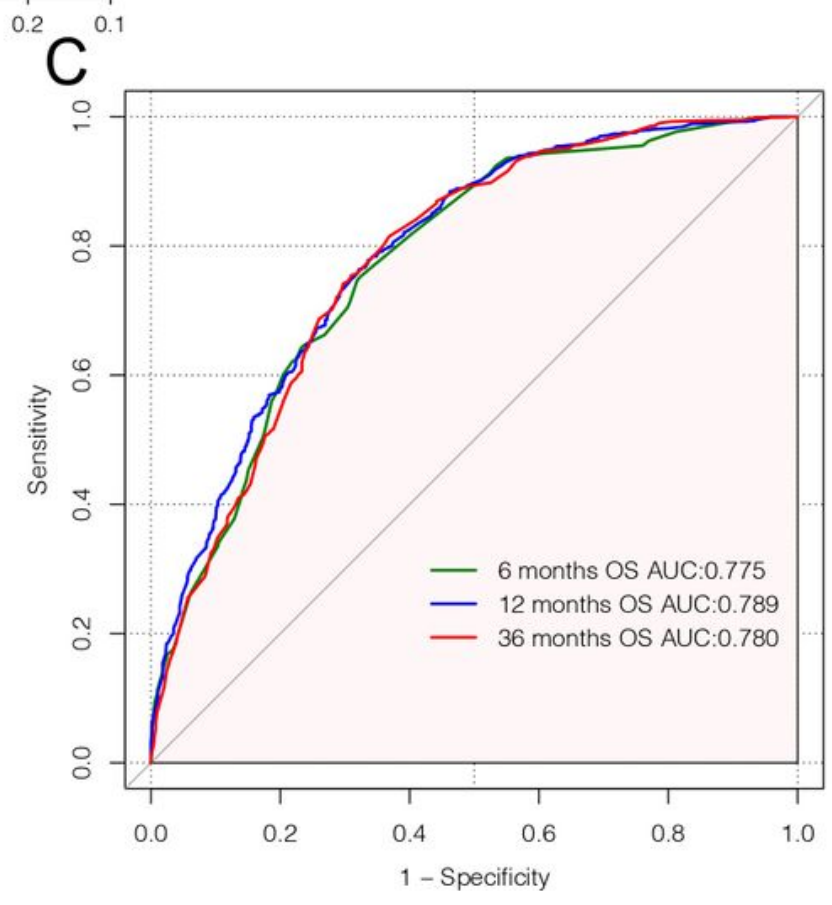

\section{Figure 6}

Generation and validation of the nomogram composed of prognostic risk model and clinicopathological characteristics for overall survival. (A) Nomogram to predict overall survival. (B) The calibration curve of nomogram between the predicted probabilities of survival and the 45-degree line. (C) The area under the ROC curve was used to show the discrimination of the nomogram. 
A

Points

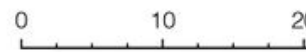

$20 \quad 30$

40

50

60

70

80

90 100

Age

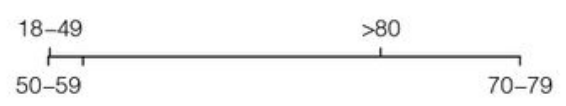

AJCC_stage

Tumor_size

Localization

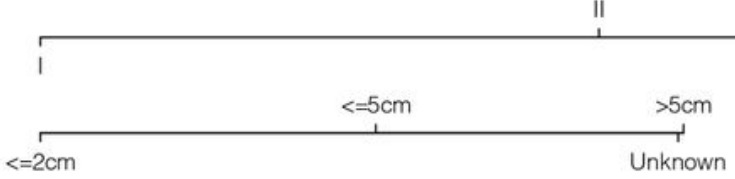

Surgery

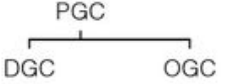

Surgery

Chemotherapy

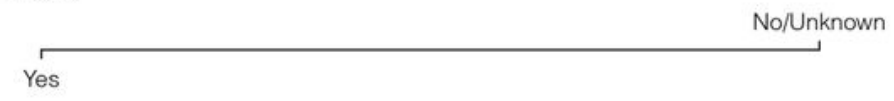

Total Points

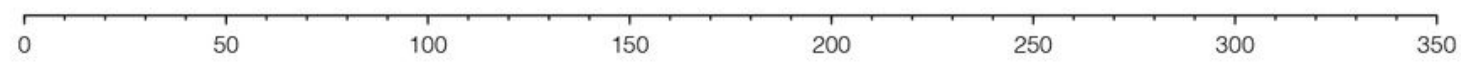

6 months Survival

12 months Survival

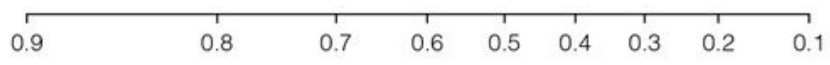

36 months survival

B

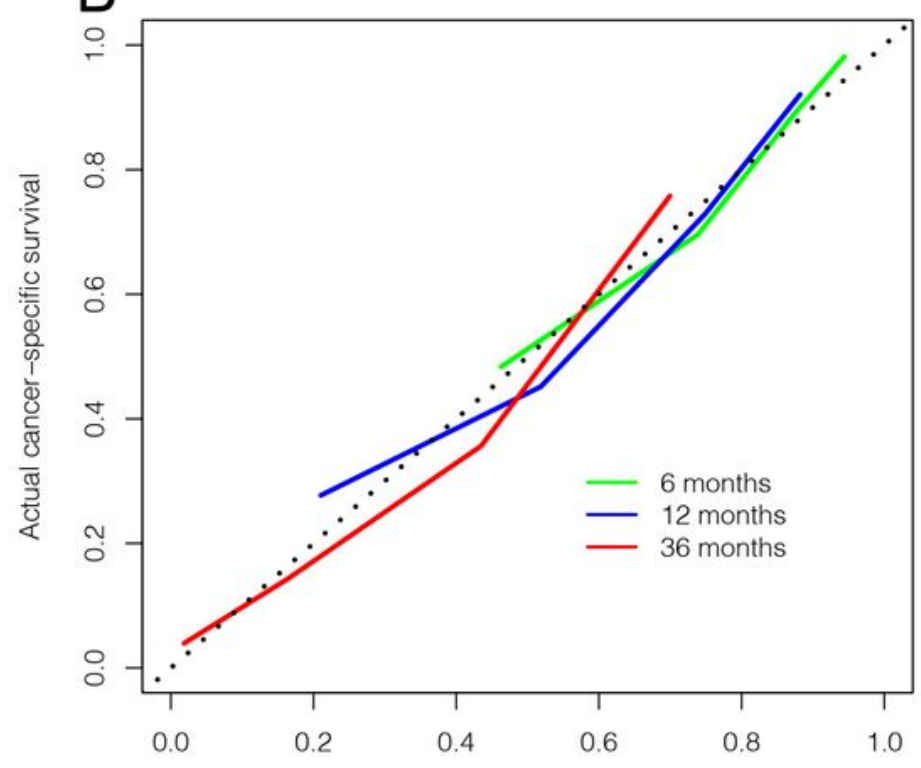

Nomogram-predicted probability of cancer-specific survival

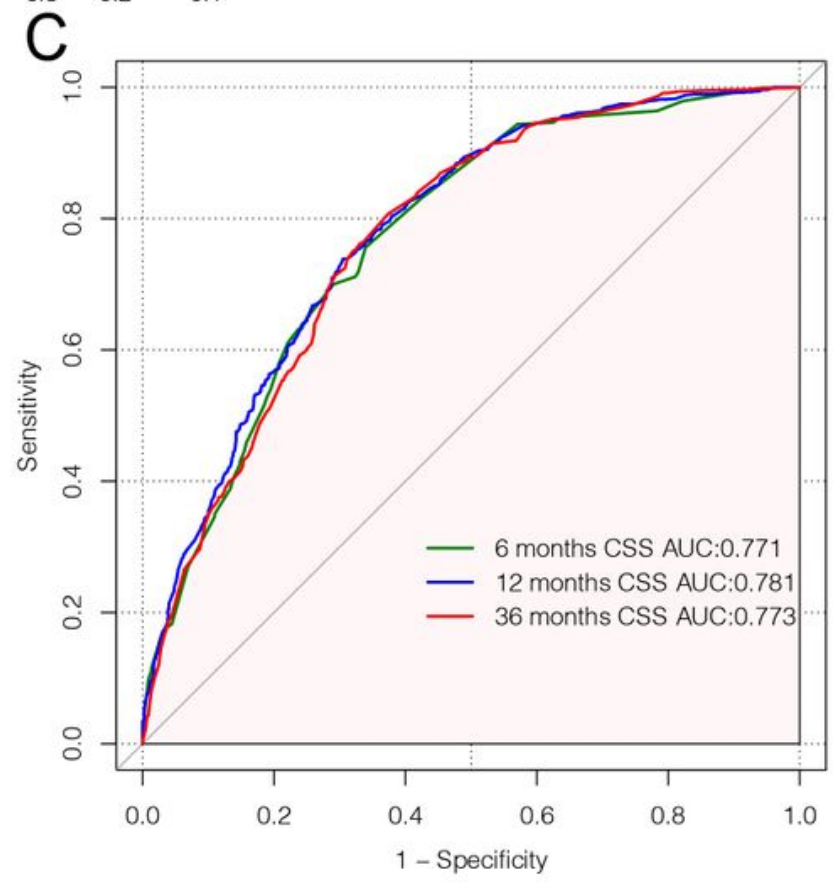

\section{Figure 7}

Generation and validation of the nomogram composed of prognostic risk model and clinicopathological characteristics for cancer-specific survival. (A) Nomogram to predict cancer-specific survival. (B) The calibration curve of nomogram between the predicted probabilities of survival and the 45 -degree line. (C) The area under the ROC curve was used to show the discrimination of the nomogram. 